\title{
"Approaching the Global Polity"
}

Morten Ougaard

CSGR Working Paper No. 42/99

October 1999
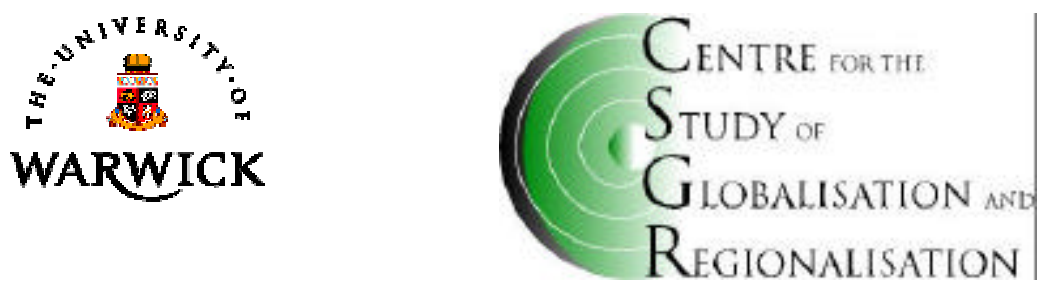


\title{
Approaching the Global Polity
}

Morten Ougaard

Copenhagen Business School

CSGR Working Paper No. 42/99

October 1999

\begin{abstract}
:
The world is becoming increasingly tightly organised politically and the global polity is emerging as a major research theme. Well defined conceptualisations and theoretical approaches have still to be developed but important contributions and insights are found in theories on regime-formation and institutionalisation, the literature on globalisation, convergence and diversity, neo-Gramscian world order analysis, internationalisation of the state and transnational and trans-governmental relations. The paper discusses main themes in these literatures and identifies promising avenues for further research, among them trans- governmental relations and transnational class-formation.

Finally the conceptualisation of the global polity is discussed and a definition suggested. The global polity is defined as the totality of global political structures and processes including non-state actors. It is further specified by three analytical aspects: a set of structured arenas, mechanisms for global policies, and embodiment of relations of power.
\end{abstract}

Keywords: Global polity, global governance, regimes, convergence, international institutions, internationalisation, globalisation, non-state actors, transnational class formation, internationalisation of the state.

Address for correspondence:

Morten Ougaard

DICM, Copenhagen Business School

Dalgas Have 15, 2000 Frederiksberg

Denmark

Mo.ikl@cbs.dk.

(Until December 15 ${ }^{\text {th }}$, 1999: CSGR) 


\section{Contents:}

\section{Introduction 1}

The "global polity" as a problem 1

Premises 7

An idiographic endeavour 7

Geographic differentiation 9

Paradigm dependency 9

\section{International Institutionalisation 11}

Contours of consensus 11

Limitations 15

\section{The functionalist perspective 17}

Selected arguments 17

Possibilities and problems 21

Potential 24

4. Loss of autonomy and pressures for convergence 25

Still room for manoeuvre? 25

Pressures for convergence 29

Internationalisation of the state 31

\section{Transnational relations 34}

Transnational actors 34

Transnational class formation 35

\section{Conceptualising the global polity 41}

Global politics is global politics 42

Seyom Brown and Robert W. Cox on the global polity 44

Specifications 47

1. Structure and Agency 47

2. Policy functions 47

3. Power and social forces 48

4. The role of "ideational" factors 50

5. Institutional forms 51

6. The developmental perspective 56

\section{Conclusion 57}

\section{References 64}

Morten Ougaard 


\section{INTRODUCTION ${ }^{1}$}

\section{The "global polity" as a problem}

The phenomenon I want to discuss has not yet acquired a generally accepted name. It is discussed under headings like the institutionalisation of world politics, world or global governance or governance without government, the global polity, the world polity, or the world political system. A sample of definitions and descriptions are presented in table 1. Obviously many analysts share the impression that the world politically is becoming more organised, and that authoritative decisions increasingly are made through international or transnational processes. What we tentatively can label a "global polity" or "global governance system" is emerging as "part of the evolution of human efforts to organize life on the planet."2

This is not unrelated to the virtual explosion of literature on globalisation. Understandings of globalisation differ, but perhaps broad descriptive definitions can be generally accepted, for instance that globalisation is the intensification of cross-border contacts and transactions, ${ }^{3}$. They do not, however, convey the sense of profound change that is signalled by the prevalence of the term. There seems to be an element of urgency, a need for "Coming to terms with the world as a whole," ${ }^{4}$ because globalisation is carrying significant qualitative changes that have taken the integration of societies to a new stage. The world has reached "a new threshold in global economic relations and in relations between governments and their citizens," and, according to the OECD, we are entering "a new global age."6

\footnotetext{
${ }^{1}$ This paper results from the research project Globalisation, Statehood and World Order, supported by the Danish Social Science Research Council.

${ }^{2}$ Commission on Global Governance 1995, xvi.

${ }^{3}$ Holm and Sørensen 1995, 4.

${ }^{4}$ Robertson 1992, 25.

${ }^{5}$ Lawrence, Bressand and Ito 1996, 14.

${ }^{6}$ OECD 1997.
} 


\section{Table 1. Excerpts on the global polity}

Seyom Brown:

"I define the world polity as the global pattern of structures and processes for conducting and resolving conflicts and making and implementing rules" - "to the extent that enforceable laws or hierarchical power (in the sense of the capacity, if need be, to coerce outcomes) are factors in the determination of who gets what, when, and how." - "the world polity can be defined as the worldwide configuration of systems of enforceable societal relationships."

(Brown 1996, 5,7)

\section{The Commission on Global Governance:}

"the development of global governance is part of the evolution of human efforts to organize life on the planet." - "There is no single model or form of global governance, nor is there a single structure or set of structures. It is a broad, dynamic, complex process of interactive decision-making that is constantly evolving and responding to changing circumstances."

(Commission on Global Governance 1995, xvi, 4)

\section{Robert W. Cox:}

"There is no clearly definable institutional structure in place that governs the global economy." (There is) "a nébuleuse, a loose elite network of influentials and agencies, sharing a common set of ideas, that collectively perform the governance function." - "there is no formal decision-making process; but there is a complex set of interrelated networks that evolve a common economic ideology and inject this consensual outcome into national processes of decision-making."

(Cox 1997, 59-61)

\section{Robert O. Keohane}

"To discuss world politics in the 1990s is to discuss international institutions" "International institutions are increasingly important" - "the globalisation of the world economy and the expanding role of international institutions are creating a powerful form of global regulation." (Keohane 1998, 82,83, 9192)

\section{Evan Luard:}

"World Society becomes a single, interrelated political organism," "- modern politics, in other words, is global politics," "- the relevant unit of political activity today is thus no longer the national state but the world political system." (Luard 1990, 4-5, 17)

\section{Anthony McGrew:}

" Global politics describes the existence of global political processes which transcend the traditional boundaries between domestic and international politics. ... Global politics thus articulates a dominant reality of modern political life, the signal emergence of a primitive and fragile global polity."

(McGrew 1992 B, 325)

"Global governance (or geo-governance) is a term which refers to those formal and informal mechanisms for managing, regulating, and controlling international activity and international systems of interaction (e.g. the trade system)."

(McGrew 1997, 15)

\section{Craig N. Murphy:}

"One of the best ways to explore global governance, what world government we actually have had, is to consider the history of world organizations, those intergovernmental and quasi-governmental global agencies that have (nominally) been open to any independent state" (Murphy 1994, 15) (Emphasis added).

John G. Ruggie:

The essays in Constructing the World Polity neither defines, nor discusses the concept "world polity." But a major concern throughout all the essays is "how the modern society of nations governs itself."

(Ruggie 1998, 100)

Susan Strange:

[Concerning] "the international political economy as a whole", "politics could be defined as those processes and structures through which the mix of values in the system as a whole, and their distribution among social groups and individuals was determined."

(Strange 1996, 34) 
Discourses on "the global polity" can be seen, then, as reflecting a perceived need to come to terms with political aspects of globalisation. Although the definitions and descriptions in table 1 differ in significant ways, it is recognisably the same reality they try to capture theoretically. This, in itself, is an indication that some sort of global polity is emerging, and it is not difficult to find empirical justification for this. Long established international institutions are as salient as ever, the number of international agreements and organisations has been growing over the last decades, and recent institutional developments points in the same direction. ${ }^{7}$

It is, I think, no coincidence that researchers have offered a plurality of terms to identify the evolution of the global polity. International political institutionalisation is apt as a characterisation of the process, but somewhat awkward as a name for the resulting structures or patterns, and "the international political system" has become too heavily identified with the realist model of anarchy. None of the terms global or world polity, or global or world governance has yet emerged as the lead contender for the title. Traditional alternatives from the study of international relations, for instance the classic international organisation, or a possible neologism like "the international/global regime architecture" have not, apparently, offered themselves as attractive solutions. One likely reason is that there is broad agreement that the "polity" is not a world government, not even an embryonic one. On the contrary, many writers find it important to dissociate themselves explicitly from any teleological notions of an evolutionary process in that direction. Consequently, researchers have been reluctant to use terms from the study of national political systems when addressing the global polity - although they are creeping in, as is evident in table 1. Another probable reason is that

\footnotetext{
${ }^{7}$ Pertinent data are found in McGrew 1992 A, Zacher 1992, Jacobs 1994, and Keohane 1998.
} 
the phenomenon is fairly new, has evolved rapidly over the last decades, and is very complex. It takes on too many forms to be captured in a fully satisfactory way by any single label.

Robert W. Cox described the difficulty neatly by naming the phenomenon nébuleuse. "Nébuleuse" means nebulous, vague, woolly, but it is also a noun, used in astronomy where English speakers use the Latin "nebula." According to a French dictionary the term refers to "tout corps céleste dont les contours ne sont pas nets", and following the Encyclopedia Britannica it was "formerly applied to any object outside the solar system that had a diffuse appearance and could not be resolved telescopically into a pointlike image." In other words, Cox's remarks indicate that in the political realm a new combined national/international pattern is emerging, something that is real and visible, but whose precise contours and properties cannot be mapped by conventional methods of inquiry.

Classical Marxism, in a way, offers a convenient short label for the phenomenon. After all, a central idea in Karl Marx's historical materialism was, as briefly summarised by Friedrich Engels, that "in every historical epoch, the prevailing mode of economic production and exchange, and the social organisation necessarily following from it, form the basis upon which is built up, and from which alone can be explained, the political and intellectual history of that epoch." ${ }^{\prime 8}$ Leaving aside whether this summary is too deterministic to truly capture Marx's dialectical approach, ${ }^{9}$ when transferred to the age of globalisation the proposition must imply that an increasingly internationalised economy is associated with the evolution of an internationalised political superstructure. Paradoxically, however, this theme is surprisingly underdeveloped by writers in this tradition, ${ }^{10}$ whereas international institutionalisation has

\footnotetext{
${ }^{8}$ Marx and Engels 1998, 1.

${ }^{9}$ According to most modern writers in the tradition it is. See for instance Eric Hobsbawm 1997 (1984). Marx and History. In Eric Hobsbawm On History, New York: The New Press, 157-170.

${ }^{10}$ Robert W. Cox and Craig N. Murphy are exceptions to this, as evidenced by the quotes in table 1 . A decade
} 
become a major theme in other research orientations. This absence is sufficiently intriguing to warrant a few comments.

The peculiar absence of Marxist analyses of the international political superstructure is, probably, due to a long theoretical shadow cast by Stalinism and the cold war. Much critical thinking and theorising were influenced by Lenin's analysis of imperialism and the Stalinist dogmatisation of that theory. The notions that capitalism could bring no real progress to the undeveloped world and had entered a period of general decay, crisis, war, and revolutions, and that durable peaceful co-operation among capitalist great powers were impossible, ${ }^{11}$ these notions were difficult to challenge from within the tradition of historical materialism. Especially so in an era when cold war rigidities tended to define the terrain of the debate. Somehow this Stalinist legacy created an intellectual climate in which the negative side of capitalist development monopolised analytical attention, also for independent, anti-Stalinist and anti-Soviet Western Marxists. In this climate capitalism's progressive side - clearly acknowledged by Marx ${ }^{12}$ - was at best under-emphasised and at worst not only ignored but also denied and explained away. ${ }^{13}$ Along with it, apparently, went the obvious hypothesis that is: obvious from a classical Marxist perspective - that economic internationalisation is associated with the development of an international political superstructure.

Turning back to the main line of the argument, it is clear that many researchers believe, with good empirical reasons, that the world for some time has been approaching what tentatively

\footnotetext{
ago, the present writer did point to the possibility for studying international political institutions from a historical materialist perspective, but did not develop the theme much further, Ougaard 1990. The theme is virtually absent from Fred Halliday's exposition of the "historical materialist paradigm," even as a possibility to be discussed. Halliday 1994.

${ }^{11}$ These claims were not far off the mark concerning the first half of the century, but widely so in most respects concerning the second.

${ }^{12}$ Aside from the Communist Manifesto, probably the most succinct brief presentation of Marx' dialectical position - equally appreciative of capitalism's constructive and destructive consequences - is found in Marx 1853.
} 
can be called a "global polity." 14 Obviously the quotes in table 1 disagree about how far this process has gone and how coherent the resulting "polity" is but there do seem to be a noteworthy evolution in perceptions over time, from e.g. McGrew's 1992 notion of “a primitive and fragile global polity" to the same writer's 1997 description of "geo-governance" and Keohane's 1998 notion of "a powerful form of global regulation."

At minimum then, we can conclude it is time to pose the question: how to approach the global polity theoretically? The excerpts in table 1 show that proposals already exist. However, relevant questions have also been explored in other theoretical contexts, and the conceptualisation of the global polity will benefit from an assessment of insights generated by several bodies of literature. Some focus on developments in the international field, especially the large literature on international institutions, some on the impact of international developments on domestic matters, i.e. debates on convergence, diversity, and resilience, and the impact of internationalisation on domestic politics; and some cut across the traditional distinction between "international" and "domestic" and focus for instance on transnational relations. All these are relevant because a significant aspect of globalisation is that "the line between domestic and foreign policy continues to blur," ${ }^{15}$ and, in the words of Milner and Keohane: "internationalisation of the world economy should sound the death-knell to the anachronistic divisions, institutionalized in universities, between "comparative politics" and "international relations." 16

What follows, then, is an attempt to bring this discussion forward through a critical discussion of several contributions that, in my judgement, have provided valuable theoretical and/or

\footnotetext{
${ }^{13}$ Exceptions are Warren 1980 and Cardoso and Faletto 1979.

${ }^{14}$ More writers could be added, e.g. Zacher 1992.

${ }^{15}$ U.S. President 1997.

${ }^{16}$ Milner \& Keohane 1996, 257.
} 
empirical insights into the "global polity". First, however, some basic assumptions and principles guiding for discussion must be presented.

\section{Premises}

\section{An idiographic endeavour}

This point is important and requires some elaboration. The distinction between idiographic and nomothetic research was introduced by the German philosopher Wilhelm Windelband (1848-1915). ${ }^{17}$ The word idiographic is not to be confused with ideographic, stemming from the Greek ideo and referring to human concepts and, exactly, ideas. Ideography thus normally means the representation of ideas by signs, hence Chinese characters are called ideograms. Idiographic derives from the Greek idio, referring to what belongs in particular to or is a unique property of something, as in idiosyncratic. Nomothetic research seeks common properties and general laws covering a class of phenomena; it is a generalising research strategy. Idiographic studies in contrast seek to develop concepts and theories that capture the uniqueness and particular laws of development for a single phenomenon. Theories about the general path of development of democratic capitalist societies are nomothetic; theories about American exceptionalism or the Japanese business system are idiographic.

Idiographic research purposes have often been associated with hermeneutic methodologies and epistemologies, but this close link is not a necessary one. Idiographic research is not bound to focus on "ideational factors" as the only or the primary source of explanation; nor does it exclude assumptions about rational behaviour. ${ }^{18}$ Idiographic analysis can explain a unique agricultural system as resulting from rational adaptation to a particular physical

\footnotetext{
${ }^{17}$ Riedel 1973.

${ }^{18}$ The antinomy between idiographic and nomothetic employed here differs from the one between ideographic and nomothetic introduced in Katzenstein, Keohane, and Krasner 1998, 682.
} 
environment. The core of the distinction between idiographic and nomothetic research is one of research purposes, not necessarily one of epistemology or ontology. ${ }^{19}$

The two types of research are complementary. Often the identification of what is unique as a matter of logic requires an understanding of what is common, and vice versa. Furthermore, idiographic analysis of a unique phenomenon often will require generalisations about its constituent parts. A theoretical model of the Japanese business system requires general statements on the behaviour of Japanese firms, and therefore depends on nomothetic research. However, the results from such studies are aggregated into one idiographic model of the Japanese business system, and this is not just a simple addition of statements, it requires organising and substantive concepts defined to capture the essence of the topic at a correspondingly higher level of abstraction.

The global polity calls for idiographic research for the basic and simple reason that there only is one. Indeed, the global governance system is not the only phenomenon of a singular nature that is of great interest to international relations research. As noticed by Barry Eichengreen, "It is hard to imagine a field of international relations in which unique situations ... were excluded because the lack of an adequate, comparable group of situations." ${ }^{20}$ There was only one Cold War, there is only one UN, only one set of Bretton Woods institutions, one Asian financial crisis, one global climate, one superpower, and so on. The challenging question is not what is common to world politics today and 500 years ago, but what is new. Diachronic comparisons with earlier periods are very useful, but they are so exactly because they shed light on what is a unique world historic process of development. Approaching the global polity theoretically means embarking on an idiographic venture. It can draw heavily on input

\footnotetext{
${ }^{19}$ Ougaard 1995.

${ }^{20}$ Eichengreen 1998, 1012.
} 
from nomothetic studies into its constituent parts - types of states, groups of institutions, classes of actors, etc. It also can use general insights into human behaviour and societal development generated by nomothetic research efforts and theories. However, when fitting the pieces together, overarching concepts that capture central features of the "whole" are needed.

\section{Geographic differentiation}

The global polity is obviously a very composite phenomenon. It has components that are global in scope, along with quasi-global, regional, cross regional and sub-regional elements. The system is one of "complex international governance ... in which different kinds of partial

orders, varying in regional scope and function, coexist." ${ }^{21}$ A closer analysis must be conscious of differences in geographical scope of the various aspects and modalities of the global polity. Distinctions must be made, for instance between the core of developed market democracies, the wider area composed of this core and the "emerging economies", and the entire world society. However, in the present context a number of theoretical issues are found to be sufficiently general to be discussed without much consideration of this, but it should be kept in mind that most of the issues discussed call for and allow geographical differentiation.

\section{Paradigm dependency}

The analysis of the global polity in the context of globalisation is an analysis of political phenomena in a societal context. This brings fundamental questions from political science in general into play: what is politics, how do we analyse it, and how do we conceptualise the state and its relations to society. It also brings fundamental questions about structure and agency, institutions and behaviour, rationality, and the relative importance of material and ideational factors into play. It is familiar that different theoretical answers to such questions 
exist: liberal, pluralist theories of the political system, statist approaches, structural-functional approaches, and state theories developed in the historical materialist tradition. Fundamentally, theoretical discussions and disagreements in international relations research, when approaching the global polity, are those of political science in general, and indeed of all the social sciences.

The answer to the question how to approach the global polity, then, depends much on the basic assumptions about state, politics, and society of the paradigm in which it is posed, as illustrated by the quotes in table 1 . Still, it is recognisably much the same reality the different attempts are trying to capture, and there seems to be room for productive communication and exchange across paradigmatic differences. It should be clear that the basic orientation behind this article is modern historical materialism, as represented by writers like Nicos Poulantzas, Joachim Hirsch, Bob Jessop, Robert Cox, and several others. ${ }^{22}$ The emphasis in what follows, however, is not on marking boundaries, rather it is to identify common ground and point to problems, questions, and contributions that are produced within and can be accepted from several perspectives.

\footnotetext{
${ }^{21}$ Mayer, Rittberger and Zürn 1993, 404.

${ }^{22}$ Cox 1987 and later works, Jessop 1985,1990, Hirsch 1974, 1995, Ougaard 1990.
} 


\section{INTERNATIONAL INSTITUTIONALISATION}

\section{Contours of consensus}

The impressive research effort that has been devoted to the analysis of international regimes and institutions ${ }^{23}$ has played a major role in the fields of international relations and international political economy. ${ }^{24}$ The theoretical debates and empirical studies generated by this effort have clarified important issues considerably, and in a sense, an emerging consensus is identifiable. Many disagreements remain, but most contributions revolve around a limited set of factors that influence institutionalisation, even if they disagree about their relative importance and the possibility for integrating them into a synthetic framework.

The widely accepted basic explanatory assumption is, in Keohane's words, that "international regimes depend on the existence of common or complementary interests that are perceived or capable of being perceived by political actors. This makes common action to produce joint gains rational." 25 In addition to interests, regime-theorists have focussed on the role of power - the question of hegemonic leadership in particular -, and "knowledge." The synthesis suggested by Hasenclever et al., named a "unified but contextualized rationalist theory of international regimes, ${ }^{26}$ was based on exactly the three key factors interests, power, and knowledge. Their proposal is among the most elaborate attempts at synthesis and merits some comments.

One point they in particular emphasised, in line with other contributions, was that the specific pattern of common, complimentary, and conflicting interests underlying regime formation is an

\footnotetext{
${ }^{23}$ The most precise terminology is Robert O. Keohane's in which institutions include organizations, regimes, and conventions. Keohane 1989, 3-4. Like Miles Kahler, however, I recognize the immense possibility for "definitional hairsplitting" and sometimes use the terms institution and regime interchangeably. Kahler 1995, $3 n$.

${ }^{24}$ The literature is very large. Overviews and discussions are found in Efinger, Mayer \& Schwarzer 1993, Levy, Young, and Zürn 1995, Hasenclever, Mayer, and Rittberger 1996, and. Martin and Simmons 1998.
} 
important contextual factor. The distribution of relative and absolute potential gains goes a long way to explain the possibility for co-operation, and also to understand the relative importance of other factors considered. ${ }^{27}$ Another important point concerns the way they integrated the "weak cognitivist argument" that "between international structures and human volition there lies interpretation," 28 into the synthesis. Under this heading they included the role of science and experts' consensus - embodied in epistemic communities - in informing and shaping policymaker's perceptions and priorities, a point that also is made forcefully by other scholars. ${ }^{29}$ In addition, however, they included ideas more broadly understood; i.e. not only knowledge and interpretations of existing social reality, but also ideals and visions of what ought to be. ${ }^{30}$ Furthermore, they included the strengthening of international norms under this heading, and an element of learning in world politics. Other scholars have also pointed to the latter point and argued that through previous successful efforts of regime building, governments have learned that co-operation through institutions works, and norms associated with co-operation between states have grown stronger. The theoretical specifications of why regimes are useful are not just theoretical claims: based on experience policy-makers recognise the benefits. One effect of cumulative regime-building thus is to facilitate continued institutionalisation. ${ }^{31}$

The basic strategy involved in the synthesis proposed by Hasenclever et. al. is to locate the various factors in a chain of causation, going from the context defined by the underlying pattern of interests, and the distribution of power among states, through perceptions, knowledge and ideas, and the actual process of political bargaining, onto outcomes in terms of regime formation and effectiveness.

\footnotetext{
${ }^{25}$ Keohane 1984, 78.

${ }^{26}$ Efinger, Mayer \& Schwarzer 1993, 218.

${ }^{27}$ Hasenclever et. al. 1996, 219.

${ }^{28}$ Ibid 206.

${ }^{29}$ Haas 1993, Cooper 1989, Meyer et.al. 1997.

${ }^{30}$ Similar arguments on "ideational factors" have been forwarded by other writers, e.g. Ruggie 1998, 16-22, and
} 
Not everybody will agree to this synthesis. But it does identify a set of factors that a very large part of institutionalist theory revolves around. One final point of contention, however, requires some comments. Much regime theory has been based on the assumption of the state as a rational, unitary actor, and this assumption is increasingly being challenged by the claim that domestic politics must be taken into consideration. This observation, by the way, is far from new. Foreign policy analysts have recognised it for decades, ${ }^{32}$ and in the debate between neo-realism and its critics, Bruce Andrews for instance argued that the external behaviour of states differ due to differences in history, domestic structures and institutions, values, and culture. ${ }^{33}$ Many institutionalists probably will grant this, since one reason for arguing on the basis of that simplifying assumption seems to have been to meet the realist challenge on its own terrain, and not to accept it as the best theoretical assumption for all purposes. The exact combination of inter-state and domestic politics still gives room for considerable discussion and disagreement, which hardly is surprising, since it brings into play basic issues concerning the conception of the state and its autonomy in relation to society. ${ }^{34}$ Still, it seems to be broadly accepted that domestic politics matter and must be considered when explaining regime formation and effectiveness, and this has been given new emphasis in recent years by the notions of "two level games" and "Double edged diplomacy."35

From the perspective of the global polity the most significant message involved here is the possibility that international politics is becoming increasingly double-edged, as Peter Evans argued in the conclusion to the 1993 volume just quoted. ${ }^{36}$ His argument does rest on a limited set of cases and an impressionistic interpretation of general trends, but on the other hand,

\footnotetext{
Brown 1992, 169.

${ }^{31}$ Keohane 1984, 79.

${ }^{32}$ Rosenau. 1971, Kegley and Wittkopf 1987.

${ }^{33}$ Andrews 1984, Wendt 1992.

${ }^{34}$ Moravchik 1997 brings these themes to the forefront.

${ }^{35}$ Putnam 1988.
} 
increased double-edgedness would be a slow-moving tectonic process of change not easily assessed empirically. In other words, although systematic empirical evidence is limited it is plausible that diplomacy in general is becoming increasingly double-edged. (This is not to say that it necessarily is becoming democratic, the domestic players in a two-level game can be a rather narrow set of special interests). The consequence is that domestic patterns of political alignment gain importance in shaping foreign policy and the politics of international institutionalisation. This is important, because it implicates that the "blurring of the line between domestic and international politics" ${ }^{37}$ is a two way street. Much attention has been given to internationalisation's impact on domestic policy and institutions, but the discourses on "twolevelness" point to the reverse process: domestic forces and processes are increasingly penetrating international politics. A process of mutual interpenetration between the domestic and the international is underway. The dual nature of this phenomenon is important. If you focus solely on the first side, you get a picture of domestic forces being subjected to a powerful, actorless process of internationalisation. If you focus on the other side, an element of empowerment appears: individuals, political parties, interest groups etc can influence events in the outside world, including the politics of institutionalisation.

In sum, institutionalist theory has made a convincing case that institutions are created and do matter, and it has identified a set of main explanatory factors: shared interests, the power of states, knowledge and ideas, domestic politics, and learning. There is still disagreement about their relative weight, and about the possibility for developing a satisfactory synthesis, but thanks to the theoretical and empirical contributions from many regime theorists, we now know much about the conditions under which institutions are created and become effective.

\footnotetext{
${ }^{36}$ Evans 1993.

${ }^{37} \mathrm{Cf}$ section 1 .
} 


\section{Limitations}

This impressive body of research, however, also has limitations. One is that a wider perspective has been downplayed. After all, in Keohane and Nye's seminal 1977 book the analysis of regimes was one component - although a major one - in a larger inquiry. The "first major question" on their agenda was "what are the characteristics of world politics under conditions of extensive interdependence?"38 The central focus was regimes, but the purpose was a wider one: to understand the nature of the changes in world politics resulting from increased interdependence, in other words a research agenda similar to the one addressed here: the political aspects of internationalisation or globalisation. In ensuing years, however, the main body of regime theory has not systematically addressed questions about patterns in regime-formation and the nature of the resulting overall "regime architecture." One reason, probably, is the strong focus on proving that institutions matter, ${ }^{39}$ but another and equally important reason seems to be that the goal has been nomothetic theory, i.e. general statements about regimes, not about the resulting totality of international institutions. The result, in a sense is a body of "micro-theory" of international institutions, whereas the "macro-theory" of global institutionalisation is underdeveloped. This is, by the way, not only a problem from the perspective of the global polity. It also calls into question the possibility of a strong nomothetic general theory of regimes because, as argued by Vinod Aggarwal, regimes are often "nested" in "meta-regimes." 40 That is to say that their formation and roles can only be understood if their situation in the wider institutional set-up is considered. It probably will be very difficult to develop a strong explanatory theory without taking this into account. When approaching the global polity, the insights from nomothetic institutionalist theory are indispensable, but they are not sufficient because the cumulated results are little explored.

\footnotetext{
${ }^{38}$ Keohane \& Nye 1977, 19.

${ }^{39}$ Martin and Simmons 1998, 757 make a similar point.

${ }^{40}$ Aggarwal 1998, also Ougaard 1999.
} 
Another theme that has been downplayed, perhaps for similar reasons, is the link between growing interdependence and institutionalisation. The basic idea is, in the words of Robert O. Keohane: "that as long as technological change prompts increased economic interdependence, and as long as threats to the global environment grow in severity, we will observe a continuing increase in the number and complexity of international institutions, and in the scope of their regulation. " ${ }^{41}$ It must be emphasised that this is not a one way causal relationship. International institutions, especially the trade and monetary regimes, have contributed significantly to economic internationalisation, and institutions have facilitated co-operative behaviour among states. In Keohane's words, "globalisation and international institutionalisation are mutually contingent." ${ }^{42}$ In addition, economic and environmental interdependencies are not the only relevant factors, security issues, weapons technology, the evolution of international norms, and other factors have also played a role. Furthermore, the insights summarised above have clearly demonstrated that the link is neither simple, nor mechanic. Growing interdependence as a rule of thumb increases the "demand" for institutions, but the "supply" depends on critical factors relating to distinct patterns of interests in the issue-areas involved and how they are perceived, to the distribution of power and the practice of hegemonic policy, and to domestic politics.

Nevertheless, the idea of a causal relationship between interdependence and institutionalisation has remained an important underlying theme informing much thinking about international institutions. It also has empirical support in the evident broad historical correlation between increased internationalisation and growth in international institutions, ${ }^{43}$ but while some researchers have focussed on it, it has not been at the centre of theoretical attention. The idea,

\footnotetext{
${ }^{41}$ Keohane 1993, 285-286.

${ }^{42}$ Keohane 1995, 184.

${ }^{43}$ See note 6.
} 
which has a functionalist argument at its core, seems highly relevant in the context of the global polity, and the potential contributions from this link of causation is considered next. ${ }^{44}$

\section{THE FUNCTIONALIST PERSPECTIVE}

\section{Selected arguments}

A selection of pertinent functionalist arguments is presented in table II. In one sense, they differ fundamentally because they are derived from different theoretical traditions. ${ }^{45}$ In another sense, however, they recognisably share a pattern of reasoning. If we leave aside the basic theoretical differences, the contributions can roughly be divided into 2 groups. The first deals with functions toward the economy, the other with functions toward the persistence of society as a whole.

\footnotetext{
${ }^{44}$ I will not enter the debate on the legitimacy of functional explanations in the social sciences. My contention is that they can be employed in ways that are not based on circular reasoning and are teleological only in the sense that they assume purposeful human behaviour.

${ }^{45}$ Other typologies of public goods or state functions that could be considered in the international context are found in Cerny 1995, 608-610, and Zürn 1998, 224-231, both inspired from Theodore Lowi's distinctions between regulative, distributive, and redistributive policies, and in Strange 1996, 73-82.
} 


\section{Table II: Functionalist Arguments}

Commission on Global Governance:

In "the global neighbourhood, citizens have to co-operate for many purposes: to maintain peace and order, expand economic activity, tackle pollution, halt or minimize climate change, combat pandemic diseases, curb the spread of weapons, prevent desertification, preserve genetic and species diversity, deter terrorists, ward off famine, defeat economic recession, share scarce resources, arrest drug traffickers, and so on. Matters requiring nation-states to pool their efforts - in other words, calling for neighbourhood action - keep increasing."

(Commission on Global Governance 1995, 42)

\section{Joachim Hirsch:}

Economic growth is imperative for capitalist reproduction. If growth depends on preconditions that cannot be established through the market alone, the capitalist state will provide them to the extent possible. (Paraphrase of Hirsch 1974, 27-29)

The specification of these functions is historically contingent; it "requires an investigation of the concrete historical development of the process of capitalist reproduction and of the consequent transformations of the conditions for capitalist growth and of class relations." (Translated from Hirsch 1974, 27-28)

\section{Robert O. Keohane:}

"interdependence creates interests in cooperation" (Keohane 1984, 8)

"International institutions exist largely because they facilitate self-interested cooperation." - "Institutionalism expects that as long as technological change prompts increased economic interdependence, and as long as threats to the global environment grow in severity, we will observe a continuing increase in the number and complexity of international institutions, and in the scope of their regulation." "Institutionalism also expects existing organizations to adapt quite easily to new purposes, within limits set by basic interests." (Keohane 1993, 285-286)
"Logic of capital" Marxists

State functions:

General preconditions for capitalist production: property rights and a legal system to support them, a monetary system, weights, measures and other standards,

Material preconditions: infrastructure to the extent it cannot be established by private business,

Qualification and reproduction of the labour force (health, education, welfare)

Stabilisation of cyclical fluctuations

(Summarised from Altvater 1972 and Läpple 1973.)

Craig N. Murphy:

Overall: "the tasks associated with allowing capitalist industrialism to expand across existing political boundaries, especially the task of creating and securing wider international markets to promote new industries.” (Murphy 1994, 43)

Groups and subgroups of tasks as evolved 1850-1985:

Fostering industry: infrastructure, industrial standards and intellectual property, trade, management

Managing potential social conflicts: Labor, agriculture, other older sectors, LDCs

Strengthening states and the state system: public order and administration, public finance, conflict management, managing interstate conflicts, refugees

Strengthening society: Human rights, health, education and research, relief and welfare Environmental Issues.

(Summarised from Murphy 1994, tables 3, 6, and 8)

\section{Nicos Poulantzas:}

The state has the particular function of constituting the factor of cohesion (-) of a social formation." it is "the regulating factor of its global equilibrium as a system." -"the cohesive factor of a formation's unity."

- "the state has a function of 'order' in political class conflicts, and also of global [meaning general or overall] order (of organisation in the broad sense) as the cohesive factor of unity."- "a global function of cohesion."

(Poulantzas 1978, 44-51) 
"To presume the presence of governance without government is to conceive of functions that have to be performed in any viable human system -." "Among the many necessary functions, for example, are the needs wherein any system has to cope with external challenges, to prevent conflicts among its members or factions from tearing it irretrievably apart, to procure resources necessary to its for preservation and wellbeing, and to frame goals and policies designed to achieve them. Whether the systems are local or global in scope, these functional needs are ever present if a system is to persist intact through time."

- "a prime task of inquiry is that of probing the extent to which the functions normally associated with governance are performed in world politics without the institutions of government." (Rosenau 1992, 3, 7)
Mark W. Zacher and Brent A.Sutton

Neoclassical economic theory specifies "conditions that must be satisfied if socially optimal amounts of resources are to be produced. - Neoclassical theory then posits that when these conditions do not exist, governmental regulation will enhance total welfare gains .." - "The circumstances or conditions in which the ideal neoclassical model does not hold are commonly referred to as "market failures".

"A central assertion of this book is that where these eight market failures exist to a significant degree, regimes directed at their "correction" will probably increase total welfare gains and hence the likelihood that all or a large majority of states will realize benefits. Consequently regimes will be accepted."

(Zacher and Sutton 1996, 3, 16-26)

In the first group belongs the neoclassical theory of market failures and government action, as summarised and transplanted to the international realm by Zacher and Sutton. In this perspective, government's task is to "enhance total welfare gains" in the face of market failures. Transplanted to the international realm this leads to the general hypothesis that where such market failures exist to a significant degree, regimes will increase total welfare and are likely to be accepted. This figure of thought has striking similarities to theories of economic state functions as developed by "logic of capital Marxists," Joachim Hirsch and others. Zacher and Sutton construct the rationale for government intervention deductively from neoclassical analysis of the market, whereas the "logic of capital" school constructs it deductively from Marx's theory of capitalism. Zacher and Sutton, however, emphasise that market failures are not sufficient to bring about regime formation, and recognise the importance of the political process and the variety of interests and concerns that always will shape and occasionally block regime formation. ${ }^{46}$ In parallel, Joachim Hirsch, in opposition to the "logic of capital" school, rejects deductive analysis

\footnotetext{
${ }^{46}$ Zacher and Sutton 1996, 16-17.
} 
except at the most abstract level of theory, and insists on historical analysis to specify and explain the functions undertaken in any given period.

In the second group there also is a clear parallel between James Rosenau's notion of "the functions that have to be performed in any viable human system," and the definition of the state's overall function as being the "cohesive factor of a formation's unity," developed in particular by Nicos Poulantzas and Bob Jessop. ${ }^{47}$ For all three this includes economic functions, but encompasses also the maintenance of social order and thus a wider range of activities, which after necessary theoretical elaboration could include several of the tasks listed by the Commission on Global Governance. Poulantzas and Jessop, however does not discuss the overall function of the state in the context of international politics, and Rosenau merely opens the discussion by asking whether such functions actually are performed by international "governance without government".

Craig N. Murphy has gone further in this direction by combining the economic and the overall cohesion functions, and integrating them with a Gramscian perspective that highlights the role of ideas, in particular those of US political leaders. This perspective is then applied to world politics in a historical interpretation of the evolution of international organisations. The functions performed are parallel to those just mentioned. In summary they are economic: to secure the expansion of capitalism, and political: to maintain order within and between societies, with the added qualification that they have been projected onto the world in a specific form rooted in American liberalism. In other words, the functional needs only become operative through an agency that is shaped by American interests and American liberalism. Thus more weight is given to ideational factors, but otherwise we also see a combination of functional needs, as they arise in

\footnotetext{
${ }^{47}$ It needs mentioning that there are many ambiguities in Poulantzas' writings on the state, and his thinking developed over time. See Jessop 1985.
} 
the course of societal development, and their transformation into tasks performed by governance mechanisms through political processes.

\section{Possibilities and problems}

A functional perspective along these lines can help explain why institutions are strong in some areas and weaker in others. To illuminate the potential and weaknesses of this we can consider some examples. A list of critical precondition for economic growth will include infrastructure (transport and communication); core aspects of the international monetary system, basic international agreements concerning contracts, property rights and the movement of goods and persons; and the standardisation of weights and measures. In such cases, strong common interests created by the criticality of the functions, combined with the existence of knowledge, i.e. agreements among experts about the nature of the problem and its possible remedies, at minimum can provide an important part of the explanation for the emergence of strong institutions.

Similar explanations can be developed concerning environmental problems. In cases where strong scientific evidence identifies global or international environmental problems that are potentially harmful to economic growth, welfare, or social order, functional reasoning will expect some kind of international regulation to emerge. ${ }^{48}$ Looking ex post at institutionalisations that have taken place, this perspective will look for the criticality of the problems in question as one key explanatory factor. In the same manner, the functional perspective could address the development of international co-operation in health issues, where for instance strong cooperation concerning the international spread of dangerous, infectious diseases should be expected. $^{49}$

\footnotetext{
${ }^{48}$ Keohane 1993 quoted in table II, Zacher 1992, 76-79. See also Meyer et.al. 1997.

${ }^{49}$ Cooper 1989, Zacher 1992, 79-80.
} 
Development assistance is another policy area to which functional explanations can be applied. Activities to support the development of economic infrastructure, the provision of education and basic health, and creation of political institutions underpinning a market economy, can all be interpreted as the provision of critical preconditions for economic growth in countries where neither the market alone nor the local state can provide them. They are parts of what Craig N. Murphy described as "the tasks associated with allowing capitalist industrialism to expand across existing political boundaries." ${ }^{, 50}$ However, it will be difficult to develop strong functional explanations for all activities in this area. Programs that emphasise poverty alleviation and humanitarian and welfare concerns are more politically contested and more difficult to establish theoretically as necessary functions. They can be seen as addressing market failures in relation only to politically decided performance goals against which market outcomes are measured. Consequently, the explanation of such activities will rely more on domestic and international political processes and the relative strength of various political forces.

Indeed, when we move away from a core of basic functions, the relevance of the functional perspective lies rather in a negative argument: it can help explain the absence or weakness of institutions and governance in areas that are not critical to the continued operation of the international economy, or to the maintenance of basic social cohesion. In other words, outside a core of critical functions, the functional perspective must be seen in relation to political forces, and the analysis must ask: for whom is this a critical need, and what is the bargaining strength of this particular actor or group of actors?

\footnotetext{
${ }^{50}$ Murphy 1994, 43.
} 
The same difficulty is faced if functional reasoning is applied to issues of social order. International policies concerning crime, drug trafficking, and terrorism are easily interpreted as extensions of basic public order functions that must be internationalised under conditions of deep interdependence. It is also possible to extend functional reasoning to the peaceful settlement of international disputes, to peace-keeping and even peace-making. In the in the age of weapons of mass destruction and highly devastating conventional warfare a strong argument can be made that the avoidance of major wars has become critical for the persistence of societies and even that this also applies to local wars. ${ }^{51}$ The fact that this on several occasions has proven to be a difficult or impossible goal to achieve does not weaken the argument because it still can help explain why persistent efforts are made towards that effect. On the other hand, a cynical case can be made that e.g. local wars in peripheral areas or the break down of failed states poses no major threats to the international economy, or to the general stability of international society. Furthermore, the difficulties are enhanced by the fact that issues of international order are closer to key aspects of national sovereignty and security, where states' concerns about power and relative gains become more important. Consequently, explanations based on functional needs in such policy areas must rest on more problematic assumptions about the requirements for societal persistence and cohesion and on historically and politically contingent notions of the boundaries of a legitimate international order.

The list of "matters requiring nation-states to pool their efforts" suggested by The Commission on Global Governance illustrate this. It has far reaching consequences to see this list as more than a political wish. To posit it as a causal argument presupposes an embryonic global statefunction: that of securing the survival and basic rights of all of humankind. A strong normative case can be made for the need to be serious about such "world interests", and there is evidence

${ }^{51}$ Zacher 1992, 67-75. 
that such norms are making themselves felt in the global polity. ${ }^{52}$ However, to accept this as a strong explanatory principle is probably at best premature.

Aside from illustrating strengths and weaknesses of functional perspectives, these examples indicate the importance of the principle of geographical differentiation. Some functions are truly global, some relate only to the core of developed capitalist countries, while some concern relations between the core and "emerging economies" or other groupings of countries, and so on.

\section{Potential}

In sum, functional perspectives can help explain the general trend towards international institutionalisation. When national economies become increasingly integrated, "market failures" will acquire an international dimension that calls for international efforts to remedy them, and a similar argument pertains to functions of societal cohesion. They can also help explain variation across issues by focusing on the salience of the "need" for co-operation in particular areas. The guiding rule of thumb is that the more critical co-operation is for economic growth or societal cohesion and persistence, the stronger is the element of shared interests and consequently the tendency to establish institutions to address that need. But functional explanations cannot be applied in a mechanic or deterministic manner, institutionalised co-operation will only be established by actors through complex domestic and international political processes marked by widely different constellations of interests and relative bargaining strength. Functional explanations cannot stand alone. Better explanations and generalisations across issues can be developed if the nature of the "needs" addressed by institutions is considered more systematically. At least that is the promise of the functional perspective. But given the limits of the perspective, it probably would be futile to go much beyond the general rule of thumb and seek to develop a fine grained typology of functions and from this deduct hypotheses about the

\footnotetext{
${ }^{52}$ Finnemore and Sikkink 1998.
} 
likely pattern of institutionalisation in each of them. Rather, an idiographic research strategy will apply a functional perspective by seeking reasons for institutionalised co-operation in specified needs arising from economic and societal development and change, and follow the process of regime formation through political processes.

Finally, one additional potential contribution from the functional perspective should be mentioned. It helps focus on the long-term evolutionary trend towards an increasingly institutionalised and capable global governance system that many writers claim is a reality. A functional approach that brackets all the intervening variables and focus on the links between societal change and international institutionalisation is well suited to capture a long term developmental process, in which international governance capacity is enhanced across a widening range of sectors.

\section{LOSS OF AUTONOMY AND PRESSURES FOR CONVERGENCE}

\section{Still room for manoeuvre?}

The impact of economic internationalisation on nation states is a central theme in the literature on globalisation. It has evolved along two lines, one concerning the alleged loss of "Keynesian welfare state capacity," the other focussing on a broader set of convergence pressures and convergence effects on domestic policies and institutions. In both cases, a strong globalisation thesis in various guises is now giving way to more nuanced positions.

The first of these discussions has especially looked at the effects of three economic developments: the liberalisation and growth of international trade, the rise of foreign direct 
investment, and the liberalisation of capital markets. ${ }^{53}$ This has reduced the effectiveness of national demand management as a policy tool; it has constrained monetary and fiscal policies by enhanced concern for exchange rates and the possibility of capital flight due to differential inflation and interest rates; and it has in general limited the range of policy options due to the exit option of footloose capital. In strong versions of the globalisation thesis this has undermined governments' ability to use traditional fiscal and monetary policy instruments to influence growth, employment and general welfare.

It seems clear now, however, that the thesis in this strong form cannot be sustained. A number of studies, theoretical and empirical has argued persuasively that capital is not that footloose, that national economies maintain a degree of separation from each other so that significant policy differences can be sustained, especially in larger economies; and that financial markets are not much concerned about the size of the public sector and the level of taxation, but merely about the sustainability of government deficits. ${ }^{54}$ Consequently, there is still a considerable national room of manoeuvre in macroeconomic matters. Furthermore, it has been pointed out that it is not new that national economic policy-making must take the external environment into account.

In addition, the strong loss of autonomy thesis on this point can be criticised from another angle. In part of this literature a myth of a Keynesian golden age appears to be under construction. Several writers seem implicitly to take for granted that the national state once had the ability to achieve close to full employment and a fair amount of security, welfare and economic equality through Keynesian means, an ability now allegedly lost. ${ }^{55}$ The history of Western capitalism after the Second World War points to a somewhat more nuanced picture. After all, the "golden

\footnotetext{
${ }^{53}$ Discussions are found in Held 1991, Cerny 1995, Altvater \& Mahnkopf 1996, Berger \& Dore 1996, Hirst \& Thompson 1996, Strange 1996.

${ }^{54}$ See in particular Wade 1996, Hirst \& Thompson 1996, Garrett 1996, and Berger 1996.

55 The tendency is found in Cerny 1995 and Strange 1996.
} 
age" of high growth and low unemployment lasted only a decade and a half and was brought about by a historically extraordinary set of circumstances. Contemporary levels of unemployment, growth, inequality etc are perhaps not untypical when seen in a larger historical perspective. ${ }^{56}$ Hence, it is doubtful that the nation-state ever had all the economic capabilities ascribed to it now by some loss-of-autonomy writers.

Yet, even if there still is a considerable room for manoeuvre, the case has not been made that it has not been narrowed by economic internationalisation. On the contrary, the current balance of the argument is rather that it has been narrowed, but not as much as claimed by the strong loss of autonomy thesis. Furthermore, even if the case should be that constraints are not much stronger today than they have been - say throughout the century, the existence of these constraints would still be an important characteristic of the global polity and the way national states form parts of it. Partly because it means that national economic policy-making must be seen in an international context and as parts of an international political economy; and partly because this fact induces governments to seek international co-operation in macroeconomic questions. After all, a key concern in international economic diplomacy, at least since the world economic conferences in the 1930s, has been questions relating to macroeconomic policy.

There is, however, more to the process of economic internationalisation than the three issues of trade, FDI, and capital flows. The qualitative changes connected with internationalisation, as cause as well as effect, also include the consequences of growing economies of scale and heightened importance of high-technology industries. The relevant arguments in this regard are clearly enunciated in Laura Tyson's study on high-tech competition. The first point is that hightech industries are important for national economies, "not only because of their measurable

\footnotetext{
${ }^{56}$ Maddison 1991.
} 
contributions to exports, high-wage and high-skill jobs, productivity, and R\&D, but also because of their unmeasurable contributions to the nation's technological capabilities." point is that such industries almost by nature are global, and to judge from data from the World Investment Surveys, increasingly so. ${ }^{58}$ According to Tyson, "most high-technology industries are global in scope, dominated by a relatively small number of relatively large multinational companies competing in one another's domestic markets through trade and transnational investment. Scale requirements and strategic concerns motivate these companies to take a global perspective, establishing a presence in all major markets." ${ }^{59}$ It is an inescapable consequence of growing scale that high-tech companies increasingly will expand beyond the borders of national economies. These two arguments lead on to a third namely that governments will be induced to conduct strategic trade policy and other interventionist policies, due to " the characteristic features of high-tech industries - imperfect competition, strategic behaviour, dynamic economies of scale, and technological externalities." 60

Tyson's study was made during the American "competitiveness scare" of the 1980's, before the onset of the long boom of the 90's, and her main policy-concern was government intervention to enhance high-tech competitiveness. But she also made the additional claim that the consequences go beyond macroeconomic and industrial policy. Briefly put, the point is that "Competition between firms gestated in different national systems is, to some extent, competition among the systems themselves." 61 This claim is based on Michael Porter's study of the competitive advantage of nations ${ }^{62}$ and other "new trade theories", but it is also supported by "business systems" theories and similar contributions, to be discussed below. The upshot of the argument,

\footnotetext{
57 Tyson 1992, 42.

${ }^{58}$ United Nations 1992, 134-139.

${ }^{59}$ Tyson 1992, 4.

60 ibid

${ }^{61}$ Tyson 1992, 31.

${ }^{62}$ Porter 1990.
} 
then, is that global high-tech competition and the associated demand for increased scale of production are exposing entire "national systems" to intensified competitive pressures. ${ }^{63}$

This has great salience in the discussion of the consequences of economic internationalisation. The point is that it is the combination of tighter international constraints on macro-economic policymaking and intensified competitive pressures on entire domestic systems that now is a major fact of life for nation states. The reality of this combination, then, must be seen as a valid and central point in the loss of autonomy argument, the justified criticisms against the strong globalisation thesis notwithstanding.

\section{Pressures for convergence}

The literature on convergence has squarely addressed the issue of competitive and other pressures on national societies. The point made by Tyson, that competition involves not only companies and industries, but also entire "national systems", stands out particularly clear in contributions from "business systems" and similar approaches. Their shared intention is to describe and analyse the variety of distinct national ways of organising capitalist economies. Geoffrey Hart for instance uses the term "state-society arrangements", covering business-business relations, business-state relations, business-labour relations, and labour-government relations, to describe such patterns. ${ }^{64}$ In Whitley's framework the business system is described by typical patterns of organising and interaction within individual firms and between firms, but the business system is also analysed in the context of national institutions and on the background of the historical pattern of economic development. ${ }^{65}$ Other writers use concepts like "systems of corporate governance", "modes of regulation", different "industrial orders", or "an economy's system of governance ... defined as the totality of institutional arrangements - including rules and rule-making agents - that regulate

\footnotetext{
${ }^{63}$ See also Hirsch 1995 and Cerny 1995 on the "competition state."

${ }^{64}$ Hart 1992.
} 
transactions inside and across the borders of an economic system". ${ }^{66}$ In spite of differences of terminology, thematic emphasis, and specification of conceptual frameworks, this literature shares the observation that distinct national modes are not haphazard agglomerations of characteristics, but interconnected complexes, in which features at the level of the individual firm or industry are shaped by and parts of national frameworks.

In consequence, convergence pressures not only effect governments and questions of national macro-policies, but also specific sectoral policies and institutions in the private as well as the public sector. William Coleman has summarised this point in a broad and close to deterministic generalisation: "globalisation will encourage considerable convergence in economic structures; convergence in economic structures will favor, in turn, increasing similarities in political structures." ${ }^{67}$ In a parallel fashion, Berger summarised the general convergence thesis in this way: "competition, imitation, diffusion of best practice, trade and capital mobility naturally operate to produce convergence across nations in the structures of production and in relations among economy, society and state. Variations may be found from country to country, because of different historical legacies. But such distinctions fade over time..." ${ }^{, 68}$ I must be noted immediately that for both authors these formulations are the starting point for a critical discussion that focuses on limits to convergence. Indeed, like in the case of loss of autonomy, there is a convincing counterargument. Convergence is not an automatic process, but mediated through domestic politics and institutions which often have an interest in as well as the capacity to resist harmonising pressures. Indeed the convergence literature has demonstrated clearly in empirical studies (whose number seems to grow constantly) that the limits to convergence are real. ${ }^{69}$ In some policy areas and economic sectors there is noticeable convergence, but in general little micro-institutional

\footnotetext{
${ }^{65}$ Whitley 1992.

${ }^{66}$ Hollingsworth, Schmitter, and Streeck 1994, 5.

${ }^{67}$ Coleman 1996, 227.

${ }^{68}$ Berger 1996, 1.
} 
convergence has taken place. Still, the existence of convergence pressures is relevant in the perspective of the global polity. Even if they are weaker than suggested by some writers, the mere fact that policies are made in the context of such pressures must be included in the picture of nation states as parts of a global polity. The important point is that decisions concerning the international economy are made both in international institutions and by nation states operating under such pressures.

\section{Internationalisation of the state}

One of the ways in which such pressures operate deserves attention, namely that of direct crossborder contact between government agencies. In a summary and discussion of the literature on political convergence, Colin Bennett identified emulation and elite-networking as important mechanisms of convergence (along with harmonisation through international regimes and penetration). ${ }^{70}$ Robert Cox found that the OECD, the G7, IMF and BIS, in addition to their more formal roles, serve to "tighten the transnational networks that link policy making from country to country". 71 The existence and significance of such policy networks has also been pointed out by other writers. In the case of the OECD, the organization itself confirms this role: "OECD can make an important contribution to global change and policy reform through its role as catalyst and pathfinder in international economic cooperation - notably through its policy dialogue and peer pressure." 72 The OECD, according to David Henderson, is "concerned with practically the whole range of economic and social issues that are dealt with by its member governments." 73 The less formalised co-operation in the G7 forum also has a quite broad and seemingly widening scope. Furthermore, it is quite possible that such trans-governmental networks between different groups of states also have been proliferating outside the settings of the formal organisations

\footnotetext{
${ }^{69}$ Berger and Dore, 1996, Hollingsworth, Schmitter, and Streeck 1994, Unger and Waarden 1995.

${ }^{70}$ Bennett 1991.

${ }^{71}$ Cox 1992 B, 30.

72 OECD 1997, 9.
} 
mentioned here. Little research has been done on these processes and their actual impact on national governments, ${ }^{74}$ and it is possible that Berger's general conclusion - so far little microinstitutional convergence - still holds. On the other hand, at least the OECD process seems to be leading to an increasing number of recommendations to member governments, ${ }^{75}$ and the G7 Centre at the University of Toronto also found evidence of some compliance with summit recommendations among the member states. ${ }^{76}$ The possibility that we rather should expect broad bands of convergence with some room for diversity should also be kept in mind. Either way, in the present context the point is that such networks exist, at minimum as fora for discussion and "peer review", and as such make up a kind of integration between national government bodies. The implication is that national decision-making on domestic matters in a broad array of policy areas is situated in an internationalised political context. To borrow a term from sociology, an element of international reflexivity has been introduced to national policy making. Indeed, the extent to which even major states subject their internal affairs to international monitoring and peer pressure is remarkable because it marks a clear break with traditional formal conceptions of sovereignty.

Finally, it should be pointed out that the question of convergence or non-convergence could be misleading when judging the salience of such networks. The policy dialogue between governments is also concerned with new issues that present themselves in broadly similar terms to groups of countries, and when new common challenges and opportunities arise as a result of social, economic, environmental or other changes, the networks can help find common solutions to common problems and avoid unnecessary replication of analytical work. In other words,

\footnotetext{
${ }^{73}$ Henderson 1996, 13.

74 The work on compliance at the G8 Centre at the University of Toronto, available on http://www.g7.utoronto.cal, is an interesting and useful beginning.

75 Jacobs 1994.

${ }^{76}$ G8 Centre 1998.
} 
convergence is not an issue when governments at the outset co-ordinate responses to new problems.

In sum, the loss of autonomy and convergence literature gives us a mixed picture. On one hand, direct pressure from international market forces, especially in areas related to finance, the rise of competitiveness as a more pervasive and central policy goal, and other mechanisms related to economic internationalisation has lead to some reduction of national state autonomy and pressures towards convergence. In addition, international regimes, peer pressure in policy networks, and other mechanisms also entail pressure towards convergence. On the other hand, real sovereignty has not evaporated; there are important policy-areas where national policymaking is paramount and where nation-states desist and attempt to defend national society against external pressures. In parallel, nationally rooted business systems are still able to and do resist harmonising pressures in many instances. The exact balance between autonomy loss and its preservation is not known very precisely yet and must be expected to vary between nations, policy areas, and sectors. But no matter what that balance is, most of the literature on convergence and loss of autonomy share the underlying notion that national governments make and implement decisions - also concerning domestic matters - in internationalised settings, and increasingly so. This means at minimum that political agendas are affected by the external world; that effective control over outcomes in some areas only can be achieved through international cooperation; that states operate under a variety of convergence pressures; and that national political processes in many areas are parts of international policy networks.

The significant contribution from these discussions is that the global polity evolves not only through the development of international institutions, but also through the transformation of 
national states. The states are constitutive parts of Cox's "nébuleuse," and the ways in which they are changed by processes of internationalisation must be included in the theoretical portrayal of it. The literature on loss of autonomy and convergence supports the claim that while states are still relevant and maintain a considerable room for manoeuvre, the internationalisation of the state $^{77}$ is a significant feature of the global polity.

\section{TRANSNATIONAL RELATIONS}

Transnational relations have been on the theoretical agenda for decades, although not always in a prominent place. $^{78}$ The theme has appeared in two main guises, reflecting different theoretical perspectives from which they have been approached. One has focussed on concrete actors, especially NGOs and transnational corporations, and studied their role in international politics while the other has posed questions of transnational class formation.

\section{Transnational actors}

The first strand of literature has clearly demonstrated that transnational relation do matter, at least sometimes and to some extent. It deserves mentioning that the phenomenon is not new, ${ }^{79}$ and the first modern NGO was formed a century and a half ago. It is clear, however, that there has been a tremendous upswing in the formation of international NGOs over the last decades, bringing the total number beyond the 14000 mark according to one count. ${ }^{80}$ Concerning their importance in relation to the UN system, Leon Gordenker and Thomas G. Weiss found "significant evidence that nongovernmental organisations (NGOs) have joined states as participants in organised international relations." Still, "the principal participants in making

\footnotetext{
${ }^{77}$ Cox 1994, 49.

${ }^{78}$ Spiro $1994,46$.

${ }^{79}$ Risse Kappen 1995 A.

${ }^{80}$ ibid, 47.
} 
policies and executing programs in the international institutions in the UN realm remain government representatives." ${ }^{81}$ In the volume edited by Thomas Risse-Kappen case studies showed that "we cannot explain state behaviour in crucial issue-areas without taking the crossborder activities of non-state actors into account." ${ }^{82}$ Again, however, it was emphasised that the impact of such actors depends on domestic and international political institutions. Other studies have also shown the relevance of non-state actors, and especially NGOs in the fields of human rights, environmental issues, and humanitarian assistance, what is summarised as civil society based NGOs. $^{83}$ Systematic studies of the political activities of transnational corporations are scarce, but probably the picture here also will be mixed. In general, then, non-state actors seem to be influential sometimes, but overall they are secondary to governments and international institutions. There is, however, a strong indication that the impact of these activities is growing, and the conclusion must be that when approaching the global polity theoretically, the transnational activities of civil society NGOs, TNCs and other non-state actors must be taken into account.

\section{Transnational class formation}

Turning to the second group of writings on the theme of transnational relations, the picture is rather different. There is much more focus on traditional organised interests like labour, farmers, and especially business, as well as on economic issues, and the theoretical claims are stated at an aggregated level. Robert Cox has suggested the existence of a "transnational managerial class" consisting mainly of "those who control the big corporations operating on a world scale", plus public officials in national and international agencies, and a whole range of experts. Although this group does not identify itself as a class, it has "attained a clearly distinctive class consciousness" with an "awareness of a common concern to maintain the system that enables the

\footnotetext{
${ }^{81}$ Gordenker and Weiss 1996 B, 209.

${ }^{82}$ Risse-Kappen, Thomas 1995, 280.
} 
class to remain dominant." ${ }^{84}$ In a somewhat similar fashion, Kees van der Pijl argued the existence of an "Atlantic ruling class." 85 In both cases, fora such as the Trilateral Commission and the World Economic Forum at Davos, along with intergovernmental institutions like the G7, the OECD, and the World Bank Group, are identified as evidence of, as well as venues for, the development of the shared world view that holds the class together. ${ }^{86}$

These perspectives, in other words, fuse networks between governmental agencies and international institutions with transnational non-state actors into a world dominant class, united principally by a shared and hegemonic ideology. In addition to this, there is especially in Cox's contribution another central claim namely that the dominant class not only is united internally through this ideology, the dissemination of the ideology is also the principal medium for securing its dominance in the international system. This second claim, which perhaps is the most important one for Cox himself, is clearly relevant for the analysis of the global polity, but it is better discussed in a later section. In the present context the first claim, concerning the existence and nature of a transnational ruling or dominant class is the significant one.

The claim is not immediately comparable to those forwarded in the literature on transnational relations, in part because of the underlying epistemological and ontological principles. There is, in the tradition inspired by Marx, more to the concept of class than empirically observable behaviour. A classical starting point for discussing this theme is the distinction between class "an sich" and class "für sich", the point being that a class can exist "an sich", as a group of individuals sharing the same position in the division of labour, without being a class "für sich" which requires a shared understanding of the interests to be articulated on this basis, as well as

\footnotetext{
${ }^{83}$ Clark 1995, Spiro 1994, Reinicke 1998, 101.

${ }^{84}$ Cox 87, 358-359

${ }^{85}$ Pijl 1984.

${ }^{86}$ See also Gill 1990, 48-50, 217.
} 
capacity for joint political action. ${ }^{87}$ (This by the way also shows that contrary to widespread perceptions, the class perspective is not necessarily deterministic; writers in the tradition including Marx have always maintained a strong moment of "social constructivism".) The claims that there is a transnational ruling class, then, combine the an and für sich perspectives when pointing out that there is both a shared structural position in the global division of labour and a shared world view.

To substantiate the existence of a class an sich is an operation of theoretical inference from analyses of production structures, property relations etc, an operation that is entirely different from the search for observable instances of actor participation in and impact on decision making processes. But when we look to the für sich aspects, the claims do become comparable to those forwarded by the transnational relations literature. The existence of organised mechanisms for the articulation of interests and especially for political action to pursue those interests as they are constructed, are central and empirically verifiable indicators of the existence of classes für sich.

The question then, is whether the existence of a transnational ruling class has been substantiated in both aspects, and this in turn depends on how restrictively one chooses the criteria. Clearly one can argue that the owners and controllers of international businesses, at least from the industrialised capitalist economies, in many ways are situated in similar structural positions in the global economy and consequently have common interests in important respects. On the other hand, research into business systems and the convergence debate discussed earlier strongly suggest that even for companies with a global presence the home country base still matters, and the resilience of national systems towards pressures for convergence indicate that there are important structurally based conflicts between national capitalisms. Evidently, there is

\footnotetext{
${ }^{87}$ Modern class theory is much more sophisticated than this simple dichotomy. It is, however, useful in the present context. For modern discussions of class theory, see Jessup 1985 and Wright 1997.
} 
widespread consensus on some basic issues, centred on the desirability of a growing and open international market economy, and there are observable institutional mechanisms through which this consensus is maintained, developed, and disseminated. Still, in light of the density of interest organisations, think tanks, political parties, etc. operating at the domestic level, and the intensity of their contacts to national governments, it seems doubtful that the existence of a transnational class has been substantiated, at least if one wants to apply the same criteria in both contexts. The Trilateral and the Davos forums do not seem to qualify for a more restrictive conception of class, even when seen together with examples of contacts between business leaders and policy-makers from national governments and international institutions. Even in Europe, where economic and political integration is most advanced, a decisive move to a situation where the international organisations are dominant in relation to national chapters has not occurred. ${ }^{88}$ Perhaps research into organisations like the International Chambers of Commerce, the World Business Council for Sustainable Development, and the International Organization of Employers may lead to another conclusion, but so far claims to the existence of one transnational ruling class in a more restrictive sense of the concept seem premature.

On the other hand, when approaching the global polity from a class perspective, it clearly no longer suffices to conceive of social classes and social forces in purely domestic terms (if it ever did). The real problem is to investigate how class formation is affected by internationalisation. In the 1970's Nicos Poulantzas tried to answer this question. He concluded that internationalisation had rendered the traditional concept of "the national bourgeoisie" obsolete, since all domestic capitalist classes in the developed countries were now firmly dependent on the internationalised economy under US hegemony. To capture the essence of this new situation he coined the term "the internal bourgeoisie", which was still constituted within the confines of nation states. ${ }^{89}$ In

\footnotetext{
${ }^{88}$ Streeck and Schmitter 1991.

${ }^{89}$ Poulantzas 1978, 72.
} 
other words, the bourgeoisies "an sich" were internationalised, while as classes "für sich" they were strictly national. Today the interesting thing to investigate is the extent to which transnational classes "fur sich" are under formation and how.

Theoretically, it is a highly plausible hypothesis that movement in that direction is happening, and not only concerning dominant classes. One reason is that economic internationalisation affects the interests, bargaining strength, and patterns of potential coalition building of domestic interest groups. $^{90}$ In particular it has been argued that the negative economic effects of internationalisation on "trade loosers" can undermine the support for economic openness, ${ }^{91}$ but the idea has wider applicability. Economic internationalisation presents new opportunities as well as new challenges for interest groupings rooted in domestic business systems, "trade winners" and "trade loosers" alike, and regime formation and international institutionalisation bring new issues on to the political agendas, around which interests are articulated and coalitions built. Keohane, partly arguing in parallel with Robert Cox, suggested that "evidence seems plentiful that in contemporary pluralistic democracies, state interests reflect the views of dominant domestic coalitions, which are constituted increasingly on the basis of common interests with respect to the world political economy." "92 To the extent that dominant coalitions in several countries share some interests in the world political economy, this amounts to the emergence of transnational classes "an sich," and a similar argument can be made concerning what in simplistic terms is called "trade loosers", who also can acquire parallel interests towards the world political economy. Combined with the internationalisation of politics, and the ensuing need to transfer political activity to the international level, this supports the expectation that transnational class formation will occur as a long-term trend.

\footnotetext{
${ }^{90}$ Milner and Keohane 1996, 244-245.

${ }^{91}$ Ibid, Frieden and Rogowski 1996.
} 
It is also possible to find examples that support the plausibility of this hypothesis. Just two illustrations: The International Chamber of Commerce is evidently trying to position itself as the leading global business organization, and it was called upon to present a business point of view to the leaders of the G7 at the 1997 Denver Summit. ${ }^{93}$ In the same vein, the International Confederation of Free Trade Unions is developing a global agenda and trying to strengthen its voice in several international fora. ${ }^{94}$

The important contribution from Robert Cox and others in this context, then, is that they have called attention to the possibility of transnational class formation, and to some evidence that such a process may be under way. But if we are to get a better picture of the "nebeuleuse", as also recognised by Cox, it is necessary to investigate this process closer, paying particular attention to the formation of transnational interest organisations, their activities, and relations to national and international political institutions. The evidence suggest that movement in that direction still is fairly limited, and given the resilience of national business systems, we should not expect a speedy process in that direction for the entire global political economy, and not even for the most integrated core of industrialised capitalist countries. However, between the two extremes of strictly national class formation and fully-fledged transnational classes there might be a growing field of shared interests and concerns that are articulated and organised transnationally. If the class perspective shall contribute more to the understanding of "the global polity", it must move beyond simplified notions of either one transnational ruling class or separate "national bourgeoisies," and look at the concrete organization of transnational business interests, as well as emerging organisations of workers, farmers, consumers, and even political parties to ascertain to what extent and how such organisations organise and pursue their interests transnationally and internationally.

\footnotetext{
${ }^{92}$ Keohane 95: 174.

${ }^{93}$ International Chamber of Commerce 1997.
} 
Briefly summarised, then, the transnational relations literature surveyed here suggests two points of relevance for approaching the global polity. One is that the participation of a variety of nonstate actors must be recognised in the conceptualisation of the "nebuléuse", among them civil society NGOs and transnational corporations. The other is that a process of transnational class formation may be under way, which calls for analytical attention to the evolution of international organisations of traditional interests like business, labour, farmers and others.

\section{CONCEPTUALISING THE GLOBAL POLITY}

The preceding sections have shown that several research agendas have approached the global polity theoretically and empirically from different angles, leading to significant insights into various aspects of the phenomenon. What now must be discussed are possible overarching theoretical frameworks in which such partial insights can be integrated. In other words, the question is how to approach the global polity as a whole, as one global polity.

Several writers have proposed conceptualisations to this effect, as evidenced by the excerpts in table 1 . Going back to the notions presented there, it is clear that they have many differences in terms of theoretical content. Some are deceptively commonsensical (Murphy), while others are explicit efforts of theoretical conceptualisation (e.g. Brown, McGrew, and Cox). Some employ concepts of politics inspired by David Easton or structural functionalism, (Strange, Brown, Young), while others are inspired by Marxist and especially Gramscian thinking (Cox, Murphy). The contributions also differ concerning their empirical referent, explicitly or implicitly. Some seem to point to the entire field of global politics (Brown, Commission of Global Governance,

\footnotetext{
${ }^{94}$ International Confederation of Free Trade Unions 1996.
} 
Keohane, Murphy), some emphasise economic issues and seem mainly, but not solely, directed towards the "international political economy" of capitalist countries (Cox, Strange), while others focus on the UN system (Meyer et.al., Gordenker \& Weiss). Furthermore, they differ concerning the strength of their explicit normative orientation, and the nature of the norms underlying such orientations.

\section{Global politics is global politics}

These and other differences notwithstanding, it is noteworthy that several definitions apply concepts from national or comparative politics to the international realm. Thus, Susan Strange advocated a definition of politics inspired by David Easton's analysis of a national political system, and Luard chose to talk about "the world political system." Seyom Brown's proposal is different, but clearly also applies concepts from general social science ("systems of enforceable social relationships"). Anthony McGrew emphasises the regulatory aspects of global governance ("mechanisms for managing, regulating, and controlling"), but again concepts known from the study of domestic politics are applied to the international realm. Other examples, not represented in the table, are Wolfgang H. Reinicke's policy suggestion that "cross-national structures of interest formation, aggregation, and representation" be developed in order to improve "global public policy," ${ }^{95}$ and Clive Archer's analysis of international organisations in terms of the political functions defined by Almond and Powell: articulation and aggregation of interests, creation of norms, socialisation, rule-making, rule application, rule adjudication, information, and operations. $^{96}$

The application of concepts from the study of national politics, of course, means a clear break with realist claims that the domestic and international realms are so fundamentally different that

\footnotetext{
${ }^{95}$ Reinicke 1998, 229.

96 Archer 1992, 159-177.
} 
they cannot be analysed by similar conceptual tools. It is unlikely that any of the writers quoted above would dispute that the global polity is lacking a centralised decision making machinery backed by a legitimate monopoly of coercive force. ${ }^{97}$ Nevertheless, the definitions signal that in spite of this, the global polity shares important characteristics with domestic political systems. Decisions are made, policies are conducted, and there are cross-national structures of interests formation, aggregation and representation. What is suggested, in other words, is a reversal of theory-building strategy. Instead of starting from the state system, and treating the rise of the global polity as a modification of this (the growth of international society, the maturing of anarchy), the global polity is taken as the theoretical starting point and defined as a proper subject for research, whereas anarchy is treated as a complication, albeit a major one. To reverse theoretical strategy in this way means drawing the full theoretical consequences of the fact that towards the end of the twentieth century, the institutionalised interaction of state and non-state actors has become a decisive feature of world politics.

If this reversal of strategy is accepted, concepts from general political theory can and must be applied to the analysis of the global polity. Still, the differences to national political systems are of major importance, and applying existing models from the study of nation states cannot alone solve the task of conceptualisation. Hence, we must turn attention to the further elaboration of conceptual models of the global polity.

As a starting point for this discussion, it is useful to consider the contributions from Seyom Brown and Robert W. Cox because they are among the more elaborate attempts to come to terms theoretically with the global polity. A juxtaposition of these two contributions rises a number of

\footnotetext{
${ }^{97}$ As I finalize this manuscript in late April 1999, NATO, in the shadow of the Kosovo-conflict, is taking steps towards establishing itself as such a monopoly for an unspecified part of the globe.
} 
issues that will help develop a conceptualisation of the global polity, when discussed in the light of conclusions from preceding sections and a few additional contributions.

\section{Seyom Brown and Robert W. Cox on the global polity}

Brown defined the global polity as "the world-wide configuration of systems of enforceable social relationships." What interests us now is how this definition was further elaborated to identify theoretically key characteristics of this entity. This was done through three separate claims. The first one is that the polity includes not only the "prevailing configuration of governance", but also "efforts directed toward changing the prevailing configuration."98 The definition includes the process of ongoing change, of negotiation and re-negotiation, in which contending forces try to shape the "configuration of governance." Both structure and agency, in other words, are included in the definition. Second, for Brown the global polity consists of four subsystems: 1) the state system, including intergovernmental organisations, 2) transnational nongovernmental organisations and movements, 3) the domestic systems of government, and 4) the individual as political actor. These subsystems are open to each other, and for Brown this interpenetrability is an important premise for a general theory of the world polity. Thirdly, the contending forces present in the system and shaping its development are "a myriad of overlapping and crosscutting alignments and antagonisms." The main dividing lines, according to Brown, go between champions and opponents of open global markets, supporters and opponents of universal human rights regimes, democratic and un-democratic forces, religious fundamentalists and secularists, altruists versus adherers to self-help philosophies, and other "alignments and antagonisms". In short, the global polity consists of national and international governmental institutions, and non-governmental organisations, and it is constantly evolving through a conflictual process, in which a range of policy goals and values are pitted against each other in patterns that firmly cut across national borders.

\footnotetext{
${ }^{98}$ The following is based on Brown 1996, 166-169.
} 
A remark on the normative component in Brown's theory is required. Brown writes from a strong concern with the evolution of the global polity towards a more just and humanitarian system, and he wants to develop theory that can be used for policy guidance in that direction. This is perfectly legitimate, and laudable, but what concerns me here is his contribution to the conceptualisation and analysis of the global polity as it is. However, for Brown the normative element is also part of the analytical model since the global polity as it is, partly is the result of the strength of such normative concerns. Visions, or "models of practical and just political relationships that appeal to this human constituency" is "one of the basic motive forces for change or stability of the world polity." Hereby he introduces a causative factor that rarely is considered in analyses of international institutions. Of course, the strength of this factor must be ascertained through empirical research, but given the observable strengthening of international norms, ${ }^{99}$ it would be wrong to rule it out beforehand.

Now, consider Robert W. Cox' conceptualisation of the global polity, or what he enquiringly chose to call a nébuleuse. To summarise Cox is admittedly a daring endeavour, since his contribution is a large and complex one. His wide canvas is really a theory of world history that includes technology, production structures, social forces, types of states, international orders, and hegemonic "historical blocs." But when focussing on those parts of the canvas that pertain directly to the international political realm, I suggest that his main claims can be summarised in 5 points:

1) The nébuleuse is a transnational decision making process, or a set of 'very complex transnational mechanisms" 100 or "elite networks" through which decisions are made or interstate

\footnotetext{
${ }^{99}$ Finnemore and Sikkink 1998.

${ }^{100}$ Cox 1997, 59.
} 
consensus formed regarding the needs or requirements of the world economy. ${ }^{101}$ 2) Such decisions or this consensus shape policies or result in public policy guidelines, ${ }^{102} 3$ ) in accordance with a hegemonic ideology, "a structure of values and understandings about the nature of order that permeates a whole system of states and non-state entities." ${ }^{103}$ 4) This hegemonic ideology reflect the power of dominant social forces, it "derives from the ways of doing and thinking of the dominant social strata of the dominant state or states insofar as these ways of doing and thinking have acquired the acquiescence of the dominant strata of other states." 104 Their base in the international production structures ultimately defines these social forces. 5) Finally hegemony is underpinned by a structure of power, consisting of "a larger and more complex political structure that is the counterpart to international production", of which the nation states are parts. ${ }^{105}$ This "international political structure" "appears to be more evolved, more definitive, in some of its parts; less formed, more fluid, in others: and the connections between the parts are more stable in some cases and more tenuous in others."106

Several points emerge from this brief juxtaposition of Cox' and Brown's contributions. The points are closely interrelated and can only be clearly separated analytically; hence, the order of exposition in what follows is somewhat arbitrary.

\footnotetext{
${ }^{101}$ Cox 1987, 253, Cox 1992 B, 30.

102 Cox 1997, 59.

${ }^{103}$ Cox 1992 A, 151.

${ }^{104}$ ibid. See also the discussion of transnational social forces in section 5 above.

${ }^{105}$ Cox 1987, 253.

106 ibid 258.
} 


\section{Specifications}

\section{Structure and Agency}

The first point is in a sense very simple, but also very basic. Cox, like Brown, conceptualises the global polity in terms of structure as well as agency. The nébuleuse consists of processes of decision making and consensus formation, as well as political structures. In Susan Strange's terms, the global polity is to be thought of as political processes and structures. The point may seem trivial, but it is important.

\section{Policy functions}

The second point is that both writers recognise that policies are carried out through the "nébuleuse", it performs policy functions, whether through international institutions or national states. For Cox, the role of the nébuleuse in shaping policies or policy guidelines is a key feature, whereas for Brown this aspect is downplayed in the explicit conceptualisation, but clearly present, for instance in the discussion of "functional international organizations" and in references to the global polity as "a system of governance." For Cox the functions are much geared towards the needs of the world economy, whereas Brown has a broader perspective, but the idea that the global polity somehow results in international policies is common to them. Other writers share this notion, and indeed make it the centre of their understanding of the global polity. Reinicke, for instance, focuses on "global public policy," McGrew centers his definition of "geo-governance" on "mechanisms for managing, controlling, and regulating international activity and international systems of interaction," and Keohane points to "a powerful form of global regulation."

The notion that the global polity contains mechanisms for conducting policies clearly is in congruence with several contributions discussed earlier. The literatures on regimes and 
institutions, convergence, and internationalisation of the state all pointed to performance of international or internationalised policy functions, although through different institutional forms, going from strong international organisations to weakly harmonised national policies. These discussions underscored, however, that such functions often are contested and that there are real and substantial limits to harmonisation and convergence. Disagreement probably will persist as to how strong the actual governance capacity is, but it seems difficult to deny that there is some such capacity, and that it is strong in some policy issues. Consequently, when conceptualising the global polity this aspect is necessary.

\section{Power and social forces}

The third point emerging from a comparison of Brown and Cox is the question of power and social forces. On this the two contributions differ, since for Cox the nébuleuse clearly is a manifestation of relations of power, and not between states, but between social forces. There are ambiguities in Cox's formulations - for instance are hegemonic ideology and political structures mutually reinforcing but independent, or are the one creating or enabling the other, and if so, which has primacy? Such questions are neither trivial nor simple to answer at the level of abstract theory, and in a way, they are reminiscent of the intricacies concerning the relations between state institutions, the power of social classes, and hegemony encountered by historical materialist state theory. ${ }^{107}$ Nevertheless, in the present context what is particularly relevant is the emphasis on power. The nébuleuse has a clearly hierarchical quality, whether through hegemonic ideology or political structures or both, and in Cox's perspective the outcomes in general favours some interests to the detriment of others. Cox, of course, is not alone in pointing to this, and in this regard Cox can be taken as representative of a large body of critical literature. Brown's perspective, in contrast, paints a more open and fluid picture, in which the global polity per se

\footnotetext{
${ }^{107}$ See Jessop 1990, Ougaard 1990.
} 
seems not to be structured so as to favour particular interests systematically. Cox's specification of the power relations is open to criticism, to be discussed shortly. The focus on power and distributional issues, however, within and among societies, and the recognition that the global polity is far from neutral in this regard, or at the very minimum cannot be assumed to be neutral, must be included in the conceptualisation of the global polity.

The critical remarks concerning Cox's contributions require a caveat. In numerous passages he acknowledges that matters are more complex than his general propositions imply, they are to be read as identifications of major and central features, not as exhaustive analyses. Still, it is necessary to point out some problems that are under-emphasised or under-theorised in his contribution. One is that he seems to paint a too harmonious picture of the dominant social forces, and in particular of the dominant transnational ruling class. Recalling the resilience of national business systems in the face convergence pressures and the problems of transnational class formation discussed in preceding sections, it must be stressed that hegemony is marked by internal conflicts and antagonisms. The claim that there is "a common economic ideology"108 can be substantiated, but it covers far from all issues, and within this broad frame of consensus there is ample room for conflict. The shape of the global system of "governance without government" cannot be reduced to the expression of one single hegemonic social force or historical bloc. Rather, we should see the nébuleuse as the institutionalisation of negotiated compromises that reflect relations of power but also are permanently subject to re-negotiation and adjustment in accordance with shifting "correlations of forces."109

In addition, Cox's theory contrasts with Brown's portrait of "a myriad of overlapping and crosscutting alignments and antagonisms." The advantage of Cox's social forces perspective is

\footnotetext{
${ }^{108}$ Cox 1997, 61.

109 The theoretical concept "correlations of forces" in my judgement is one of the very few valuable contributions
} 
that it can help order and prioritise the agglomeration of policy stances described by Brown, and answer questions about their societal sources, as well as questions about the effects of outcomes on social groups and actors. But Brown rightly points to a wider field of issues and forces than those enumerated by Cox, and in particular to issues and institutions that are not directly related to the "needs of the world economy." Human rights and other humanitarian concerns, peaceful conflict resolution, arms limitation; and institutions and actors engaged in such matters should not be downplayed. Such issues may be seen through the lens of a global function of persistence, as discussed earlier, but even then, as also argued they are much more politically contested and contingent than core economic functions. Consequently, conceptualisations of the global polity must be open to this wider range of issues and forces.

\section{The role of "ideational" factors}

To Brown and Cox alike ideas and values play a role in the global polity, but in different ways. Robert Cox apprehends ideational factors through the lens of hegemony. Hegemony is "a structure of values and understandings" that "derives from the ways of doing and thinking of the dominant social strata of the dominant state or states insofar as these ways of doing and thinking have acquired the acquiescence of the dominant strata of other states." 110 The role of ideas is closely tied to the power of specific social forces, and, indeed, it seems that the interest for ideas derives mainly from the effort to understand the mechanisms that make the perpetuation of dominance possible. For Seyom Brown there is a greater variety of ideas at play in the global polity, and they are not so tightly tied to specific social forces, at least not to social forces explicitly based in relations of production. Rather he points to a looser set of policy stances across a range of issues. Of particular interest, however, is Brown's claim that there also are universal norms based on "world interests" that represent the shared concerns of humankind. 
Visions, or "models of practical and just political relationships that appeal to this human constituency" is "one of the basic motive forces for change or stability of the world polity."111 Hereby he introduces a causative factor that is downplayed in most analyses of international institutions, although discussed extensively in the so-called "international society" school and in literature on global governance. It can be seen as an expression of "the concretisation of the sense of humankind" that Ronald Robertson identified as a key aspect of globalisation. ${ }^{112}$ Of course, the strength of this factor must be ascertained through empirical research, but given the observable strengthening of international norms, it would be wrong to rule it out a priori. May be the existence of ideas that express such "world interests" can be said to be included in Cox's notion of hegemony, but this does not appear to be a quite satisfactory solution. If both critical perspective and analytical power is to be maintained, it seems necessary to recognise a distinction between ideas and values that are specific to "the dominant social strata", and "world interests" in Brown's sense. For instance, ideas about universal human rights may have specific historical origins, but it is difficult to see how the case can be made that they reflect the exclusive concerns or interests of specific social forces defined by their basis in economic structures. Furthermore, even a critical perspective like the one entailed in Cox seems to gain in sharpness and strength, politically as well as theoretically, if the existence of "world interests" is recognised in principle, and distinguished clearly from ideas of the "dominant strata of the dominant states".

\section{Institutional forms}

The fifth point concerns the institutional form of the global polity. On this, Brown and Cox clearly agree to emphasise complexity as an outstanding characteristic, and in doing so they join many writers, as evidenced by discussions in preceding sections. Indeed, if one should identify

\footnotetext{
111 Brown 1996, 169.

${ }^{112}$ Robertson 1992, 104.
} 
the most prevalent descriptor of the global polity in the literature, complexity would be a likely candidate.

Brown captures complexity by describing the global polity as consisting of four subsystems that are mutually interpenetrating. Leaving aside for the time being the question of non-state actors, the central observation covered by Brown's notion of interpenetration seems to be that the global polity, in institutional terms, consists of international organisations and institutions, as well as nation states in both their domestic and international roles. This understanding of the global polity goes well with the themes of institutionalisation, convergence, internationalisation of domestic politics, and double-edged diplomacy discussed in previous sections. The global polity takes on a variety of forms, including international organisations proper, regimes, conventions, and policy-networks between governments, all of which can be further differentiated according to institutional forms along several dimensions, ${ }^{113}$ and it includes not only intergovernmental affairs, but also the domestic roles of nation states. Cox also concurs, although he does not go quite as far as Brown in discussing institutional forms. Indeed, his use of the term nébuleuse signals the difficulty of drawing a clear picture, but one reason for this seems to be exactly that states are being internationalised ${ }^{114}$ at the same time as they become parts of a larger transnational political structure.

Brown, in addition to the notion of interpenetration, describes the polity as polyarchic, since it neither has a "central system of order and justice", nor a "dominant hierarchy of power."115 Here is a contrast to Cox, who emphasises hierarchy and power as central features of the global polity. The difference should not be overstated, however. Brown is well aware of inequalities and injustices in world society, and part of his criticism of the "prevailing configuration of

\footnotetext{
${ }^{113}$ Preston \& Windsor, Kahler, el al.

${ }^{114} \mathrm{Cf}$ section 4 above.
} 
governance" is based exactly on the observation that it addresses such injustices inadequately. What differentiates the two writers is rather that Brown refutes that there is one dominant hierarchy, and paints a more fluid picture than Cox. One reason for this difference is that Cox focuses on political economy issues, whereas Brown takes a broader perspective and is more interested for instance in humanitarian concerns. Another important reason is the familiar one that the two writers base their contributions on different societal ontologies.

To carry this discussion one step further, and leaving aside the basic ontological issues, it is useful to divide the question in two, one concerning power, and one concerning the lack of "a central system of order" in the global polity. Concerning power, it should be possible to identify common ground in the sense that the institutional pattern of the global polity is not neutral, but represents institutionalisation of relations of power. The disagreement then, is about the nature of these relations, and not about their existence at all. This is to be discussed further below.

The second issue concerns the institutional pattern directly. Here Cox on one hand refers to the nebulous nature and complexity of the global polity, but on the other hand subsumes this quality under the notion of hegemony, which signals some sort of coherence or underlying rationality. Brown's notion of polyarchy, on the contrary signals a multi-centered and far less coherent system. The ambiguity in this reading of Cox, however, can be remedied if the notion of hegemony is understood in a way that incorporates exactly the institutional complexities that are emphasised by Brown. A brief glance at the empirical record, as well as much of the existing literature, will support a conceptualisation along such lines. The global polity is a multi-centered ensemble of institutions that must be differentiated according to geographic and functional scope, but cannot be described by neat divisions of functions or clear-cut roles, but rather as "a loose set

\footnotetext{
${ }^{115}$ Brown 1996, 166.
} 
of cross-national policy patchworks conspicuous for its missing links and unnecessary overlaps". ${ }^{116}$ It is far less coherent than any national system of governance or state, and indeed, its lack of coherence is emerging as a political issue. ${ }^{117}$ It is polyarchic or multi-centered, and although centres of decision-making differ in importance, there is not one decisive or preeminent centre. Neither the G7, the UN, the Bretton Woods institutions, nor any single state or network between governments is the centralised decision-making unit for the global polity. The point then, is that both features should be incorporated in the theoretical understanding of the global polity: it can be analysed as institutionalised relations of power, but it is also multicentered and polyarchic.

This takes us some way in terms of theoretical specification of the institutional side of the global polity. Complexity, nation states and international institutions in a pattern of interpenetration, relations of power, and polyarchy and multi-centeredness are important characteristics. An additional specification, however, that can help bring order to the complexity, merits attention. It is found in Clive Archer's discussion of the roles of international organisations. ${ }^{118}$

Archer's subject is international governmental organisations in the traditional sense of the word. This is only a subset of the global polity as discussed here, but still his discussion is of interest in the broader context. Archer defines three roles: instruments, arenas, and actors. International organisations are instruments when they are responsible for carrying out policies on behalf of the governments that control them. As arenas, international organisations provide structured political spaces where governmental and non-governmental actors meet and engage in discussion and bargaining. Finally, they can be actors that have a measure of independent decision-making capacity and the capacity to pursue goals of their own.

\footnotetext{
${ }^{116}$ Reinicke 1998, 228.

${ }^{117}$ Ougaard 1998.
} 
Archer's notion of the instrumental role corresponds to the idea that functions are carried out through the global polity, discussed above. The observation that international organisations can play an independent actor role, of course, while under-theorised by Brown and Cox, goes well along with the recognition that a variety of state and non-state actors are involved in the political processes of the global polity. The extent to which international organisations actually do act independently, of course, is an empirical question, but Archer's examples do substantiate that some of them in some circumstances do so. Consequently, the theoretical understanding of the global polity also should recognise this kind of actors. The most significant addition from Archer's suggestion, however, comes from calling attention to the arena role, and the analytical distinctions involved here apply not only to IGOs, but also to the global polity as a whole. When concerned with institutional patterns, it is important that the global polity not only contain "mechanisms for carrying out policies", but also structured political arenas. Again complexity is an obvious qualifier since there are global and quasi-global arenas like the UN and the WTO, regional arenas, and a criss-crossing multitude of other arenas, including the network of traditional bilateral diplomatic relations, which also are parts of the global arena. How these arenas are structured, for instance concerning principles governing access for government and private actors, decision-making rules etc, such matters are important characteristics of the global polity. Indeed, this is an obvious and important instance of the reality that the polity is an embodiment of relations of power. Hence, when we focus on the institutions of the global polity, their triple roles must be recognised: as agencies for policy, as structured arenas, and, in certain cases, as independent actors. The application of these straightforward distinctions appears to be a useful specification of the concept.

${ }^{118}$ Archer 1992, 132-159. 


\section{The developmental perspective}

The last point concerns the long-term evolutionary perspective. Brown's focus is squarely on the shortcomings of the global polity, when measured against the desideratum of global governance in accordance with "world interests", but he does recognise that some progress has occurred in this direction. ${ }^{119}$ In this he joins a large group of scholars who claim that there is a discernible long-term progressive evolution of the global polity, no matter how fragile and marked by setbacks it has been. In contrast, Cox by focusing on the functionality towards the needs of the global economy, under-emphasises the long-term trend towards a more co-operative global polity. Historical change in the "longue duree" plays a major role in Cox's work. But each successive stage of development is interpreted as the rise of a new world order reflecting a new hegemonic set of social forces, and the possibility of some sort of historical progress is perhaps not absent, but at least under-theorised. This is not however a necessary implication of Cox's critical perspective. On the contrary, it is possible to combine the critical perspective that focus on relations of power, with an appreciation of the evolution of consensual norms and institutions that represents principles that are rooted in the shared concerns of humankind. The development of democratic political cultures and institutions in western societies, through a conflictual process pitting social forces against each other, can serve as a template for this combination. Even if each new stage of institutionalisation is imprinted deeply with the marks of historically specific social forces under whose hegemony it takes place, critical theory can recognise the cumulation of such institutions over time. ${ }^{120}$ The claim, of course, is not that the process is inevitable or irreversible, but that it has happened and can continue. This combination, by the way, of a critical perspective that highlights power, conflict and inequalities, with a long term evolutionary perspective is indeed compatible with Marx's conception of the progressive side of capitalist development. The

\footnotetext{
${ }^{119}$ In Chapters 2 to 6 in Brown 1996.

${ }^{120} \mathrm{Cf}$ the historical account in Murphy 1994.
} 
upshot of this discussion then, is that the long-term evolutionary perspective should be included in the conceptualisation of the global polity, and not only as a normative component.

This was the sixth point that arose from the juxtaposition of the contributions from Seyom Brown and Robert Cox concerning the concept of the global polity. The remaining task is to summarise the discussion, but this is better done in the context of a conclusion to the entire argument of this article.

\section{CONCLUSION}

Parsimony is a valuable quality but oversimplification is also a danger, and the foregoing discussion strongly suggests that a theoretical approach to the global polity must distinguish between several questions and aspects. First, it is useful to distinguish between the causal explanation of the rise of the global polity and the question of conceptualising it as such.

The first of these questions in its turn can also be subdivided in two. In a broad historical perspective, the evolution of the global polity is the result of several factors. Much attention has been given to technological development and economic internationalisation, calling forward new demands for international co-operation, and this has clearly been important. But this is far from the only explanatory factor. Research has also recognised the shared experiences from two hot world wars and a cold one, leading to increased valuation of the norms of peaceful rule-based cooperation; the process of de-colonisation and the ensuing development of new relations between the so-called first and third worlds; the rise of trans-border and global environmental problems; as well as the lessons learned from previous successful exercises in international co-operation. Furthermore, an account of why the global polity has evolved as it has must recognise the role of the United States in shaping the international order after World War II, as well as the European 
integration efforts in itself and as an inspiration for other co-operative efforts. The evolution of the global polity is the result of a world historical process, in which several societal processes of change have interacted.

The second sub-question concerns the explanation at a lower level of aggregation of singular cases of institutionalisation. In this regard institutionalist theory has produced and substantiated a list of explanatory factors, revolving around interests, power, knowledge and ideas, and domestic politics. There is not yet a generally accepted model of how they interact, but rather an understanding that it depends on the particular configuration of interests, power and knowledge in each case. Whether a truly general nomothetic theory of institutionalisation going beyond this claim is possible at all remains to be seen.

Moving on to the question of the global polity as it is; i.e. how to conceptualise the "system of global governance" that is the result of decades of international institutionalisation, another set of distinctions is called for. The first derives directly from seeing the global polity as a political system, albeit not a centralised one. The polity encompasses structure or institutions, as well as agency, the conscious and purposeful behaviour of societal actors, motivated not only by concerns for immediate material interests, but also by ideals and visions. This is why "global polity" is a better nomer than "geo-governance" or the global "governance system", since the "nebuléuse," while clearly encompassing elements of governance, also includes a broader set of political processes.

When approaching the agency aspect of the global polity, the significant upshot from the previous discussions is that multiple actors of different kinds are involved: Governments and government agencies, international governmental organisations in their actor roles, civil society 
NGOs, international interest organisations, and transnational corporations. This is hardly news, but one further point of potentially great import was made: the evidence pointing to a beginning process of transnational class formation, and the plausible expectation that this trend will continue. To understand "agency" in the global polity is not only to recognise the transnational activities of actors rooted in specific societies, but also to recognise the possibility of transnational organization of interests as a significant area for further research.

The question of agency also brings fundamental issues concerning the relations between state and society into play, in particular the question of the relative autonomy and independent role of the state vis-à-vis non-state actors and interest groups. In the state-theoretical perspective informing this article states are to be seen both as acting on their own, pursuing their roles as guardians of societal cohesion and persistence, and as representatives of dominant domestic coalitions, the specific combination of the two being historically and politically contingent. A purely pluralist theory of the state will only recognise the second aspect, or at least emphasise it heavily. ${ }^{121}$ In both schools of thought, however, while states are recognised as the pre-eminent category of actors in the global polity, they are not the only relevant ones, and they are not themselves independent of non-state actors and interests.

Turning to the institutional side of the global polity, the first fundamental point is that it is a composite, multi-centered ensemble of institutions based on formally sovereign nation states. The global polity has evolved on the basis of the anarchical state system, and not through for instance empire building or world federalism. Next, international institutionalisation takes on several forms, major ones being international governmental organisations, regimes, and conventions. One form, however, needs particular emphasis; namely, that of policy networks

${ }^{121}$ Moravchik 1997. 
between states and the associated changes at the domestic level. It is insufficient merely to add together nation states and international institutions; a concept of the global polity must also reflect the internationalisation of the state and the mutual interpenetration of the domestic and international spheres.

In consequence, specifications of the concept that cut across the distinction between domestic and international are required. The preceding discussion suggests a threefold conceptualisation, based on interrelated but analytically separable perspectives.

In the first perspective the global polity is conceptualised as a set of structured but contended political arenas, through which states and non-state actors can pursue goals and interests. It includes formalised diplomatic arenas in a multitude of international fora, such as the UN General Assembly, the Security Council, and other bodies in the UN system, Global UN conferences, the governing bodies of the Bretton Woods Institutions and the WTO, the OECD, regional and cross-regional fora, less formalised policy networks between governments in a variety of permutations, and traditional bilateral diplomatic relations. Non-state actors have access to such arenas in ways of which we have little systematic knowledge, sometimes formalised, sometimes informal, sometimes with much influence, and in other cases with little impact. The structuration of these arenas, of course, has consequences for the ability of states and social forces to affect outcomes. It hardly needs telling that the arenas are structured hierarchically and generally favours strong and rich states and resourceful non-state actors, which, naturally, is one reason why the arenas also are contested. It must also be recognised, however, that at least some arenas of the global polity are equally open to all states and some to a broad array of social forces. 
Secondly, the global polity has mechanisms for policy functions or "global public policies". Whether through international agencies or through national implementation co-ordinated or harmonised in more or less formalised policy networks, the polity results in international or global governance, i.e. political intervention in economic and civil society activities. The literature surveyed suggests that it is mainly geared towards the needs of the internationalised world economy, the protection of the environment, and the maintenance of global order and security, meaning that the global polity is the embodiment of global and quasi-global societal persistence and coherence functions. The functional core of the global polity resembles a "liberal night-watchman state." The discussion also suggested, however, that it also contains more politically contingent and less developed functions towards other "world interests" such as human rights and poverty alleviation.

Thirdly, the global polity embodies relations of power. In this connection paradigm dependency is important, since underlying assumptions determine whether power ultimately refers to states or to social forces, or both. In the present context, however, we can put these questions aside and concentrate on the shared point that the polity is not neutral. The structuration of arenas and the functions performed are the results of strategic interaction between states and non-state actors, hence reflect the relative power of actors, and the resulting outcomes generally are in accordance with the interests of the powerful. It is necessary, however, to stress the plural form. There is not one single, simple hierarchy in which one social force or state is clearly and exclusively dominant, but rather a more complex pattern, based on compromises and balances between several forces in different constellations of conflicting, congruent and identical interests. Clearly, in a social forces perspective "the dominant strata of the dominant states" are the most powerful in the global polity, but the picture is more complex. The global polity rests on negotiated 
compromises that reflect the uneven distribution of power and also are subject to continuous renegotiation in accordance with shifting "correlations of forces."

Finally, the global polity as a whole, as a unity of structure and agency, must be seen in a longterm developmental perspective. It is the result of a long historical process, and it continues to evolve through the strategic interaction of state and non-state actors. Each successive stage in institutionalisation is deeply marked by the specific configurations of interests and relations of power of the time. Still there is a discernible cumulative evolution towards an increasingly capable governance system, and a growing consensus on norms relating to peaceful conflict resolutions and co-operation, human rights, and the shared concerns of humankind. The process is highly uneven, reversible, and far from satisfactory from a number of normative considerations. Still, it is important to recognise that progress has occurred and can continue in this civilising direction.

In this long-term perspective, the preceding discussions suggested that three processes of change might be particularly significant in the current stage. One is continued interpenetration of the domestic and international spheres; another is the continued increase in scope and capacity of "geo-governance"; and the third is the possible rise in the number of truly transnational non-state actors or coalitions of actors, addressing their demands to international bodies as well as to national systems.

The global polity, then, is the political superstructure of a predominantly capitalist and increasingly democratic world society characterised by deep economic integration and intense societal interdependence between formally sovereign nation states. Overall, it can be defined as the structures and processes through which values are allocated internationally, it contains 
multiple actors including increasingly transnational ones, the main institutional forms are international organisations, regimes, and networks between internationalised nation states, it is defined by structured political arenas, mechanisms for international policy functions, and as the embodiment of relations of power. The arenas are hierarchically structured, the functions are concentrated but not exclusively so on those of a liberal "night-watchman state", and the power it embodies is mainly but not exclusively the power of dominant states and dominant strata of the dominant states. 


\section{References}

Aggarwal, Vinod K. 1998. Reconciling Multiple Institutions: Bargaining, Linkages, and Nesting. In Institutional Designs for a Complex World, edited by Vinod K. Aggarwal, Ithaca and London: Cornell University Press.

Altvater Elmar und Birgit Mahnkopf. 1996. Grenzen der Globalisering. Ökonomie, Ökologie und Politik in der Weltgesellchaft, Münster: Westfälisches Dampfboot.

Andrews, Bruce. 1984. The domestic content of international desire. International Organization, 38 (2): 321 327.

Archer, Clive. 1992. International Organizations. Second Edition. London and New York: Routledge.

Bennett, Colin.1991. Review Article: What is Policy Convergence and what Causes it? British Journal of Political Science 21 (1991) 215-233.

Berger, Suzanne. 1996. Introduction. In National Diversity and Global Capitalism, edited by Suzanne Berger and Ronald Dore, 1-25. Ithaca \& London: Cornell University Press.

Brown, Seyom. 1996 (1992). International Relations in a Changing Global System. Toward a Theory of the World Polity, 2nd edition, Boulder: Westview Press.

Cardoso, Fernando Henrique and Enzo Faletto. 1979. Dependency and Development in Latin America, Berkeley: University of California Press.

Cerny, Philip G. 1995. Globalisation and the Changing Logic of collective action. International Organization 49 (4): 595-625.

Clark, Ann Marie. 1995. Non-Governmental Organizations and their Influence on International Society. Journal of International Affairs, 48 (2): 507-525.

Coleman, William D. 1996. Financial Services, Globalisation and Domestic Policy Change, Basingstoke: Macmillan.

Commission on Global Governance. 1995. Our Global Neighborhood. The Report of the Commission on Global Governance. Oxford: Oxford University Press.

Cooper, Richard N. 1989. "International Cooperation in Public Health as a Prologue to Macroeconomic Cooperation" in Cooper, Richard N., Barry Eichengreen, C. Randall Henning, Gerald Holtham and Robert T. Putnam. 1989. Can Nations Agree? Issues in International Economic Cooperation, $178-254$. Washington D.C.: The Brookings Institution.

Cox, Robert W. 1987. Production, Power, and World Order. Social Forces in the Making of History, New York: Columbia University Press.

Cox, Robert W. 1992 A. Towards a posthegemonic conceptualisation of world order: reflections on the relevancy of Ibn Khaldun. Reprinted in Robert W. Cox with Timothy J. Sinclair. 1996. Approaches to World Order, 144-173. Cambridge: Cambridge University Press.

Cox, Robert W. 1992 B. Global Perestroika. In New World Order? Socialist Register 1992, edited by Ralph Miliband and Leo Panitch, 26-43. London: The Merlin Press.

Cox, Robert W. 1994. Global Restructuring: Making Sense of the Changing International Political Economy. In Political Economy and the Changing Global Order, edited by Richard Stubbs and Geoffrey Underhill, 45-59. Houndmills: Macmillan.

Cox, Robert W. 1997. Democracy in hard times: economic globalisation and the limits to liberal democracy. In The Transformation of Democracy? Globalisation and Territorial Democracy, edited by Anthony McGrew, 49-72. Cambridge: Polity Press.

Efinger, Manfred, Peter Mayer \& Gudrun Schwarzer. 1993. Integrating and Contextualizing Hypotheses. Alternative Paths to Better Explanations of Regime Formation? in Regime Theory and International Relations edited by Volker Rittberger, 252-281. Oxford: Clarendon Press.

Eichengreen, Barry 1998. Dental Hygiene and Nuclear War: How International Relations Looks from Economics. International Organization 52, (4): 993-1012.

Evans, Peter B. 1993. Building an Integrative Approach to International and Domestic Politics. In Double Edged Diplomacy. International Bargaining and Domestic Politics edited by Peter B. Evans, Harold K. Jacobsen and Robert D. Putnam, 397-430. Berkeley: University of California Press.

Finnemore, Martha and Kathryn Sikkink. 1998. International Norm Dynamics and Political Change. International Organization 52 (4): 887-917.

Frieden, Jeffrey A. and Ronald Rogowski 1996. The impact of the International Economy on National Policies: An Analytical Overview. In Internationalisation and Domestic Politics, edited by Robert O. Keohane and Helen V. Milner, 25-47. Cambridge: Cambridge University Press.

Garrett, Geoffrey. 1996. Capital Mobility, Trade, and the Domestic Politics of Economic Policy. In Internationalisation and Domestic Politics, edited by Robert O. Keohane. \& Helen V. Milner, 79-107. Cambridge: Cambridge University Press. 
G8 Centre 1998. University of Toronto G8 Information Centre. Compliance with G8 Commitments: From $\begin{array}{llll}\text { Denver } & 1997 & \text { to } & \text { Birmingham }\end{array}$ http://www.library.utoronto.ca/g7/evaluations/birmingham/compnew.htm.

Gill, Stephen. 1990. American Hegemony and the Trilateral Commission. Cambridge: Cambridge University.

Gordenker, Leon, and Thomas G. Weiss. 1996 A. Pluralizing Global Governance: Analytical Approaches and Dimensions. In NGOs, the UN, and Global Governance, edited by Thomas G. Weiss and Leon Gordenker, 17-47. Boulder \& London: Lynne Rienner Publishers.

Gordenker, Leon, and Thomas G. Weiss. 1996 B. NGO Participation in the International Policy Process. In NGOs, the UN, and Global Governance, edited by Thomas G. Weiss and Leon Gordenker, 209-221. Boulder \& London: Lynne Rienner Publishers.

Haas, Peter M. 1993. Epistemic Communities and the Dynamics of International Environmental Co-operation. In Regime Theory and International Relations, edited by Volker Rittberger, Oxford: Clarendon Press.

Halliday, Fred. 1994. Rethinking International Relations, Houndsmills: Macmillan.

Hart, Jeffrey A. 1992, Rival Capitalists: International Competitiveness in the United States, Japan, and Western Europe, Ithaca \& London: Cornell University Press.

Hasenclever, Andreas, Peter Mayer, and Volker Rittberger. 1996. Interests, Power, Knowledge: The Study of International Regimes. Mershon International Studies Review 40 (2): 177-228.

Held, David. 1991. Democracy, the Nation State and the Global System. In Political Theory Today, edited by David Held, 197-235. Cambridge: Polity Press

Henderson, David. The Role of the OECD in Liberalising International Trade and Capital Flows. The World Economy. Global Trade Policy 1996, 11-28.

Hirsch, Joachim. 1974. Staatsapparat und Reproduktion des Kapitals. Frankfurt/M: Suhrkamp.

Hirsch, Joachim. 1995. Der nationale Wettbewerbsstaat. Staat, Demokratie und Politik im globalen Kapitalismus. Berlin: Edition ID-Archiv.

Hirst, Paul and Grahame Thompson. 1996. Globalisation in Question. The International Economy and the Possibilities of Governance. Polity Press.

Hobsbawm, Eric 1997 (1984). Marx and History. In Eric Hobsbawm On History, New York: The New Press, 157-170.

Hollingsworth, J. Rogers, Philippe C. Schmitter, and Wolfgang Streeck 1994. Capitalism, Sectors, Institutions, and Performance. InGoverning Capitalist Economies. Performance and Control of Economic Sectors, edited by Hollingsworth, Schmitter, \& Streeck, 3-16. New York: Oxford University Press.

Holm, Hans Henrik, and Georg Sørensen. 1995. Introduction: What has Changed? In Whose World Order? Uneven Globalisation and the End of the Cold War edited by Hans Henrik Holm and Gerog Sørensen, 117. Boulder: Westview Press.

International Chamber of Commerce. 1997. Business and the Global Economy. ICC statement on behalf of world business to the Heads of State and Government attending the Denver Summit, 20-22 June 1997.

ICC Business World. The Electronic magazine of the International Chamber of Commerce. Http://www.iccwbo.org/cust/html/gloecon.htm.

International Confederation of Free Trade Unions. 1996. Sixteenth World Congress of the ICFTU, Brussels, June 25-29, 1996. Congress Resolutions, at http://www.icftu.org/english/congress.html.

Jacobs, Scott H. 1994. Regulatory co-operation for an interdependent world: issues for government. In Regulatory co-operation for an interdependent world. Paris: OECD Public Management Studies.

Jessop, Bob. 1985. Nicos Poulantzas. Marxist Theory and Political Strategy. Houndmills: Macmillan.

Jessop, Bob. 1990. State theory. Putting the capitalist state in its place. Cambridge: Polity Press.

Kahler, Miles.1995. International Institutions and the Political Economy of Integration, Washington D.C.: Brookings.

Katzenstein, Peter J., Robert O. Keohane, and Stephen D. Krasner. 1998. International Organization and the Study of World Politics. International Organization, 52 (4): 645-685.

Kegley and Wittkopf 1987, American Foreign Policy. Pattern and Process, 3rd edition, Houndsmill: Macmillan.

Keohane, Robert O. 1984. After Hegemony. Cooperation and Discord in the World Political Economy, Princeton: Princeton University Press.

Keohane, Robert O. 1989. International Institutions and State Power. Essays in International Relations Theory. Boulder, San Francisco and London: Westview Press.

Keohane, Robert 1993. The Analysis of International Regimes. Towards a European-American Research Programme. In (ed) (1993). Regime Theory and International Relations edited by Volker Rittberger. Oxford: Clarendon Press.

Keohane, Robert O. 1995. Hobbes's Dilemma and Institutional Change in World Politics: Sovereignty in International Society. In Whose World Order? Uneven Globalisation and the End of the Cold War, edited by Hans Henrik Holm and Georg Sørensen, 165-186. Boulder: Westview Press. 
Keohane, Robert O. 1998. International Institutions: Can Interdependence Work? Foreign Policy, Spring 1998, 82-96.

Keohane, Robert O. and Joseph S. Nye. 1977. Power and Interdependence. World Politics in Transition, Boston: Little, Brown \& Co.

Lawrence, Robert Z., Albert Bressand and Takatoshi Ito. 1996. A Vision for the World Economy. Openness, Diversity, and Cohesion. Washington D.C.: The Brookings Institution.

Levy, Marc A., Oran R. Young and Michael Zürn. 1995. The Study of International Regimes. European Journal of International Relations 1 (3): 267-330.

Luard, Evan. 1990. The Globalisation of Politics. The Changed Focus of Political Action in the Modern World, Houndmills: Macmillan.

Maddison, Angus 1991. Dynamic Forces in Capitalist Development. A long-run comparative view. Oxford: Oxford University Press.

Martin, Lisa and Beth Simmons 1998. Theories and Empirical Studies of International Institutions. International Organization 52, 4, 729-757.

Marx, Karl. 1853 (1972). The Future Results of the British Rule in India. New-York Daily Tribune, No 3840, August 8, 1853. Reprinted in Karl Marx and Friedrich Engels. 1972. On Colonialism. Articles from the New York Tribune and other Writings, 81-87. New York: International Publishers.

Marx, Karl and Friedrich Engels.1998 (1848). The Communist Manifesto, London: Verso

Mayer, Peter, Volker Rittberger and Michael Zürn. 1993. Regime Theory. State of the Art and Perspectives. In Regime Theory and International Relations, edited by Volker Rittberger, 391-430. Oxford: Clarendon Press.

McGrew, Anthony G. 1992 A. Conceptualising Global Politics. In Global Politics. Globalisation and the Nation State, edited by Anthony G. McGrew \& Paul G. Lewis, 1-28. Cambridge: Polity Press 1992.

McGrew, Anthony G. 1992 B. Global Politics in a Transitional Era. In Global Politics. Globalisation and the Nation State, edited by Anthony G. McGrew \& Paul G. Lewis, 312-330. Cambridge: Polity Press.

McGrew, Anthony. 1997. Globalisation and territorial democracy: an introduction. In The Transformation of Democracy? Globalisation and Teorritorial Democracy, edited by Anthony McGrew, 1-24. Cambridge: Polity Press.

Meyer, John W., David John Frank, Ann Hironaka, Evan Schofer, and Nancy Brandon Tuma.1997. The Structuring of a World Environmental Regime, 1870-1990. International Organization 51, 4: 623-651.

Milner, Helen V. \& Robert O. Keohane. 1996. Internationalisation and Domestic Politics: A Conclusion. In Internationalisation and Domestic Politics, edited by Keohane Robert O. and Helen V. Milner, 243-258, Cambridge: Cambridge University Press.

Moravcsik, Andrew. 1997. Taking Preferences Seriously: A Liberal Theory of International Politics. International Organization 51 (4): 513-553.

Murphy, Craig N. 1994. International Organization and Industrial Change. Global Governance since 1850, Cambridge: Polity Press.

OECD. 1997. Towards a New Global Age. Challenges and Opportunities. Policy Report. Paris: OECD.

Ougaard, Morten. 1990. Magt og interesser i den globale samfundsformation. Aarhus: Aarhus University Press.

Ougaard, Morten. 1995. Introduction: A Perspective on Perspectives. In To Capture the Bird's Flight: On the Interface Between Culture and Society, edited by Dorte Salskov-Iversen and Anne Marie EjdesgaardJeppesen 1-16. Copenhagen: Copenhagen Business School Press.

Ougaard, Morten. 1998. FN og global organisering. Working Paper 8/98, Danish Institute on International Affairs, Copenhagen.

Ougaard, Morten. 1999. Nafta, the EU, and Deficient Global Institutionality. In Economic Integration in NAFTA and the EU. Deficient Institutionality, edited by Kirsten Appendini and Sven Bislev, 51-66. Houndsmills, Macmillan 1999.

Pijl, Kess van der. 1984. The Making of an Atlantic Ruling Class. London: Verso.

Porter, Michael E. 1990. The Competitive Advantage of Nations. London: Macmillan.

Poulantzas, Nicos. 1978 (1974) Classes in Comtemporary Capitalism. London: Verso. French edition: Paris: Editions du Seuil.

Putnam, Robert D. 1988, 1993. Diplomacy and Domestic Politics: The Logic of Two-Level Games. International Organization 42 (3), reprinted 1993 in Double Edged Diplomacy. International Bargaining and Domestic Politics edited by Peter B. Evans, Harold K. Jacobsen and Robert D. Putnam. Berkeley: University of California Press.

Reinicke, Wolfgang H. 1998. Global Public Policy. Governing without Government? Washington D.C.: Brookings.

Riedel, Manfried. 1973. Geisteswissenschaften - Grundlagenkrise und Grundlagenstreit. In Meyers Enzyklopädische Lexikon, Band 9, 838-843. Mannheim: Bibliographisches Institut. 
Risse-Kappen, Thomas. 1995 A. Bringing transnational relations back in: introduction. In Bringing Transnational Relations back in. Non-state Actors, Domestic Structures and International Institutions, edited by Thomas Risse-Kappen, 3-33. Cambridge: Cambridge University Press.

Risse-Kappen, Thomas. 1995 B. Structures of governance and transnational relations: what have we learned? In Bringing Transnational Relations back in. Non-state Actors, Domestic Structures and International Institutions, edited by Thomas Risse-Kappen, 280-313. Cambridge: Cambridge University Press.

Robertson, Roland. 1992. Globalisation. Social Theory and Global Culture. London: Sage Publications.

Rosenau, James N. 1971 (1966). Prethories and Theories of Foreign Policy. In James N. Rosenau, The Scientific Study of Foreign Policy, 95-149. New York: The Free Press.

Rosenau, James N. 1992. Governance, order, and change in world politics. In Governance without Government: Order and Change in World Politics, edited by James N. Rosenau and Ernst-Otto Czempiel, 1-29. Cambridge: Cambridge University Press.

Ruggie, John Gerard. 1998. Constructing the World Polity. Essays on International Institutionalisation. London \& New York: Routledge.

Spiro, Peter J. 1994. New Global Communities: Nongovernmental Organizations in International Decision-Making Institutions. The Washington Quarterly 18 (4): 45-56.

Strange, Susan. 1996. The Retreat of the State. The diffusion of power in the world economy. Cambridge: Cambridge University Press.

Streeck, Wolfgang \& Philippe C. Schmitter.1991. From National Corporatism to Transnational Pluralism: Organised Interests in the Single European Market. Politics and Society, 19 (2): 133-164.

Taylor, Paul. 1993. International Organization in the Modern World. The Regional and the Global Process. London: Pinter.

Tyson, Laura. 1992. Who's Bashing Whom? Trade Conflict in High-Technology Industries. Washington D.C.: Institute for International Economics.

United Nations 1992. Transnational Corporations and Management Division. World Investment Report 1992. Transnational Corporations as Engines of Growth. New York: United Nations.

US President, A National Security Strategy for a New Century, May 1997, Washington D.C: The White House.

Warren, Bill 1980. Imperialism: Pioneer of Capitalism, London: Verso.

Wendt, Alexander. 1992. Anarchy is what states make of it: the social construction of power politics. International Organization 46 (2).

Whitley, Richard. 1992. Societies, Firms and Markets: The Social Structuring of Business Systems. In European Business Systems. Firms and Markets in their National Contexts, edited by Richard Whitley, 5-45. London: Sage.

Wright, Erik Olin. 1997. Class counts. Comparative studies in class analysis. Cambridge: Cambridge University Press.

Young, Oran B. 1994. International Governance. Protecting the Environment in a Stateless Society, Ithaca and London: Cornell University Press.

Zacher, Mark W. 1992. The decaying pillars of the Westphalian Temple: implications for international order and governance. In Governance without Government: Order and Change in World Politics, edited by James N. Rosenau and Ernst.Otto Czempiel, 58-101. Cambridge: Cambridge University Press.

Zacher, Mark W. \& Sutton, Brent A. 1996. Governing global networks. International Regimes for transportation and telecommunications. Cambrdige: Cambridge University Press.

Zürn, Michael. 1998. Regieren jenseits des Nationalstaates. Globalisierung und Denationalisierung als Chance. Frankfurt an Main: Suhrkamp. 